\title{
Controls of Caribbean surface hydrology during the mid- to late Holocene: insights from monthly resolved coral records
}

\author{
C. Giry ${ }^{1}$, T. Felis ${ }^{1}$, M. Kölling ${ }^{1}$, W. Wei ${ }^{2}$, G. Lohmann ${ }^{2}$, and S. Scheffers ${ }^{3}$ \\ ${ }^{1}$ MARUM - Center for Marine Environmental Sciences, University of Bremen, 28359 Bremen, Germany \\ ${ }^{2}$ Alfred Wegener Institute for Polar and Marine Research, 27570 Bremerhaven, Germany \\ ${ }^{3}$ Marine Ecology Research Centre, Southern Cross University, Lismore, NSW 2480, Australia \\ Correspondence to: C. Giry (cgiry@marum.de)
}

Received: 29 July 2012 - Published in Clim. Past Discuss.: 21 August 2012

Revised: 14 January 2013 - Accepted: 26 February 2013 - Published: 22 March 2013

\begin{abstract}
Several proxy-based and modeling studies have investigated long-term changes in Caribbean climate during the Holocene, however, very little is known on its variability on short timescales. Here we reconstruct seasonality and interannual to multidecadal variability of sea surface hydrology of the southern Caribbean Sea by applying paired coral $\mathrm{Sr} / \mathrm{Ca}$ and $\delta^{18} \mathrm{O}$ measurements on fossil annually banded Diploria strigosa corals from Bonaire. This allows for better understanding of seasonal to multidecadal variability of the Caribbean hydrological cycle during the mid- to late Holocene. The monthly resolved coral $\Delta \delta^{18} \mathrm{O}$ records are used as a proxy for the oxygen isotopic composition of seawater $\left(\delta^{18} \mathrm{O}_{\mathrm{sw}}\right)$ of the southern Caribbean Sea. Consistent with modern day conditions, annual $\delta^{18} \mathrm{O}_{\mathrm{sw}}$ cycles reconstructed from three modern corals reveal that freshwater budget at the study site is influenced by both net precipitation and advection of tropical freshwater brought by wind-driven surface currents. In contrast, the annual $\delta^{18} \mathrm{O}_{\mathrm{sw}}$ cycle reconstructed from a mid-Holocene coral indicates a sharp peak towards more negative values in summer, suggesting intense summer precipitation at $6 \mathrm{ka} \mathrm{BP}$ (before present). In line with this, our model simulations indicate that increased seasonality of the hydrological cycle at $6 \mathrm{ka} \mathrm{BP}$ results from enhanced precipitation in summertime. On interannual to multidecadal timescales, the systematic positive correlation observed between reconstructed sea surface temperature and salinity suggests that freshwater discharged from the Orinoco and Amazon rivers and transported into the Caribbean by wind-driven surface currents is a critical component influencing sea surface hydrology on these timescales.
\end{abstract}

\section{Introduction}

Proxy records and model simulations indicate that hydrological conditions in the Caribbean have experienced significant changes on glacial/interglacial timescales. Changes in the tropical hydrological cycle on these timescales have been associated with both the mean latitudinal position of the Intertropical Convergence Zone (ITCZ) and strength of the Atlantic Meridional Overturning Circulation (AMOC) (Lohmann, 2003; Zhang and Delworth, 2005; Carlson et al., 2008; Wan et al., 2010; Leduc et al., 2007; Schmidt and Spero, 2011; Schmidt et al., 2004; Sepulcre et al., 2011). Moreover, changes in Caribbean freshwater budget have a profound effect on the strength of the AMOC, which points to the critical role of the tropical Atlantic in mediating global climate changes (Leduc et al., 2007; Jaeschke et al., 2007).

Low-latitude climate reconstructions have designated the net precipitation ( $P-E$, precipitation minus evaporation) associated with latitudinal movement of the ITCZ as the main driver of the Caribbean freshwater budget on glacial/interglacial timescales (Leduc et al., 2007; Schmidt et al., 2004; Sepulcre et al., 2011). For example, during the early and mid-Holocene, there are indications for a more northward position of the ITCZ, which intensified precipitation over the northern tropical Atlantic and the Caribbean (Haug et al., 2001; Hodell et al., 1991), whereas today, with the position of the Atlantic ITCZ in a more southerly position, net evaporation due to enhanced subsidence contributes to the negative freshwater budget of the Caribbean (Etter et al., 1987 and references therein). However, due to the lack of suitable high-resolution proxy data that clearly resolve the 
annual cycle, the seasonal dynamics of the Atlantic ITCZ under different climate background states are not well known.

In order to investigate seasonal to multidecadal variability patterns of surface hydrology in the Caribbean Sea during the mid- to late Holocene, we use decades-long monthly resolved paired $\mathrm{Sr} / \mathrm{Ca}$ and $\delta^{18} \mathrm{O}$ records of fossil corals from Bonaire (southern Caribbean Sea) to assess changes in the oxygen isotopic composition of seawater $\left(\delta^{18} \mathrm{O}_{\mathrm{sw}}\right)$ over the last $6 \mathrm{ka}$. The $\mathrm{Sr} / \mathrm{Ca}$ ratio in coral skeletons is a proxy for sea surface temperature (SST) (Beck et al., 1992; Smith et al., 1979), whereas the coral $\delta^{18} \mathrm{O}$ reflects changes of both temperature and seawater $\delta^{18} \mathrm{O}\left(\delta^{18} \mathrm{O}_{\mathrm{sw}}\right)$, which is linearly related to sea surface salinity (SSS) (Carriquiry et al., 1994; Urey, 1947; Watanabe et al., 2001; Wellington et al., 1996). Therefore, paired measurements of $\delta^{18} \mathrm{O}$ and $\mathrm{Sr} / \mathrm{Ca}$ in coral skeletons provide a unique opportunity to reconstruct SST and SSS changes at subseasonal to interannual resolution (Felis et al., 2009; Gagan et al., 1998; Hendy et al., 2002; Linsley et al., 2006; McCulloch et al., 1994). Our study aims at better understanding the natural range of surface hydrology variability in the Caribbean on seasonal to multidecadal timescales during the Holocene, by using sub-seasonally resolved coral records and climate model simulations. Such a combined approach is still rare. Exceptions include Felis et al. (2004), Abram et al. (2007), and Yokoyama et al. (2011).

\section{Regional setting and hydrography of the study area}

Coral colonies used in this study were collected on Bonaire (Giry et al., 2012), an open-ocean island in the southern Caribbean Sea, located $\sim 100 \mathrm{~km}$ north of Venezuela $\left(\sim 12^{\circ} 10^{\prime} \mathrm{N}, 68^{\circ} 18^{\prime} \mathrm{W}\right)$. Caribbean climate is primarily forced by a co-varying pattern of SST and trade winds associated with the seasonal migration of the ITCZ (Hastenrath, 1984). Bonaire has a tropical-arid climate characterised by low annual mean rainfall ( $\sim 500 \mathrm{~mm} \mathrm{yr}^{-1}$ ) and high evaporation rate. In contrast to other less arid Caribbean Islands which receive most of their yearly rain in summer (Giannini et al., 2000), Bonaire's main rainy season lasts from October through January and is followed by a dry season between February to May with a transition period called "small rains" season (Martis et al., 2002) from June to September. The seasonal displacement of the ITCZ affects the strength of the northeast trade winds blowing over the western tropical Atlantic and the Caribbean. Trade winds weaken in boreal summer and strengthen in boreal winter and thus affect the patterns of ocean circulation and precipitation in the Caribbean.

Freshwater budget in the Caribbean suggests the influence of two major processes: (1) the local freshwater flux through evaporation $(E)$ and precipitation $(P)$ (Etter et al., 1987) over the basin and (2) freshwater input from the Amazon and Orinoco rivers by advection of low salinity water masses by surface currents (Hellweger and Gordon, 2002). Net water loss due to yearlong easterly trade winds results in

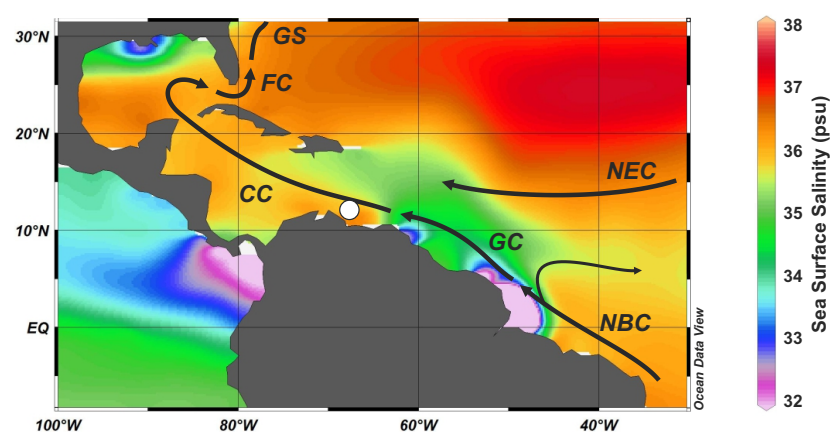

Fig. 1. Modern oceanographic setting of the Caribbean and western North Atlantic. Schematic of major surface currents constituting the upper branch of the Atlantic meridional overturning circulation (AMOC) are superimposed on annual mean sea surface salinity (Antonov et al., 2006). Major surface currents: North Brazilian Current (NBC), Guyana Current (GC), Caribbean Current (CC), Florida Current (FC), Gulf Stream (GS) and North Equatorial Current (NEC). White circle indicates the study site (Bonaire).

excessive $E$ over $P$, which is strongest over the basin in wintertime (Etter et al., 1987; Giannini et al., 2000; Hastenrath and Lamb, 1978). Caribbean freshwater budget indicates that river discharge in the western Caribbean (west of $70^{\circ} \mathrm{W}$ ) does not compensate for net water loss due to net evaporation (Etter et al., 1987), whereas it does in the western tropical Atlantic and eastern Caribbean (Hellweger and Gordon, 2002). Hence, the freshwater budget in the eastern Caribbean and at the study site might reflect both the local freshwater flux and freshwater supply from tropical rivers.

Caribbean hydrography is characterised by a stratified upper $500 \mathrm{~m}$ of the water column due to the presence of two dominant water masses with contrasting physical properties (Wüst, 1964). The North Atlantic Subtropical Under Water (SUW), formed in the subtropical north Atlantic where $E$ exceeds $P$, is characterised by a salinity maximum ( $>36.5)$ that sinks below fresher surface water referred to as Caribbean Surface Water (CSW) at about $120 \mathrm{~m}$ depth (Wüst, 1964). The latter water mass is thought to be a mixture of North Atlantic surface water and freshwater from the Amazon and Orinoco rivers, as well as from other South American rivers that is transported north-westward by the Guyana and Caribbean Currents (Fig. 1). As the CSW is transported westward by the Caribbean Current, freshwater masses are evaporated and mixed with the more saline SUW (Gordon, 1967).

At interannual timescales the tropical Atlantic is linked to the competing influence of local and remote forcing emanating from tropical and subtropical oceans. On these timescales, El Niño-Southern Oscillation (ENSO)-related anomalous atmospheric circulation is one of the dominant factors suppressing rainfall over the Caribbean. Chiang et al. (2002) suggested that the teleconnection of ENSO warm events to the tropical Atlantic results in an anomalous 
warm north/cool south SST gradient that would shift the ITCZ anomalously north; warm ENSO also induces a strong anomalous Walker circulation that suppresses precipitation over the western tropical Atlantic and Caribbean by strengthening subsidence. Such a pattern of ENSO teleconnection to the tropical Atlantic is consistent with other studies (Alexander and Scott, 2002; Giannini et al., 2001). At interto multidecadal timescales, the Atlantic Multidecadal Oscillation (AMO) plays a critical role in controlling both SST and rainfall in the Caribbean (Sutton and Hodson, 2005). Forcing mechanisms responsible for the leading large-scale pattern of multidecadal climate variability are partially related to variability in the oceanic thermohaline circulation (Delworth and Mann, 2000; Dima and Lohmann, 2007; Knight et al., 2005) as recently identified along the north-eastern coast of Brazil in the surface return flow of the AMOC (Zhang et al., 2011).

\section{Material and methods}

U-series dating, screening for diagenesis, and $\mathrm{Sr} / \mathrm{Ca}$ analyses were performed on fossil Diploria strigosa corals from Bonaire as recently described (Giry et al., 2012). Based on the annual density bands inferred from X-radiographs, a sampling resolution of $\sim 12$ samples per year was targeted along the growth axis of pristine coral skeletons. For each sample, skeletal powder was carefully drilled using a $0.6 \mathrm{~mm}$ diameter drill bit along the centre of the dense thecal walls, which is the skeletal element that provides the best environmental seasonal signal (Giry et al., 2010a). Each powdered sample was split for both stable oxygen isotope $\left({ }^{18} \mathrm{O}\right)$ and $\mathrm{Sr} / \mathrm{Ca}$ analyses performed at MARUM and the Department of Geosciences of the University of Bremen, respectively. Further details on stable isotope and $\mathrm{Sr} / \mathrm{Ca}$ analyses have been described (Giry et al., 2010a, 2012; Felis et al., 2012).

The internal chronology of individual coral records is based on annual density-banding patterns inferred from both $\mathrm{X}$-radiographs and annual $\mathrm{Sr} / \mathrm{Ca}$ cycles. Maximum and minimum $\mathrm{Sr} / \mathrm{Ca}$ values in any given year were assigned to the on average coldest (February/March) and warmest months (September/October) of present-day SST, respectively (Giry et al., 2012). This method introduces a non-cumulative error of \pm 1 month in any given year. The same anchor points as for $\mathrm{Sr} / \mathrm{Ca}$ were used for the age model construction of the corresponding $\delta^{18} \mathrm{O}$ record. To obtain monthly time series, coral $\mathrm{Sr} / \mathrm{Ca}$ and $\delta^{18} \mathrm{O}$ records were linearly interpolated to monthly resolution following established procedures (e.g. Felis et al., 2004, 2009; Giry et al., 2010b). As both $\mathrm{Sr} / \mathrm{Ca}$ and $\delta^{18} \mathrm{O}$ were measured on the same powder samples, the variation of $\mathrm{Sr} / \mathrm{Ca}$ relative to that of $\delta^{18} \mathrm{O}$ has no age uncertainty.

Subseasonal reconstruction of seawater $\delta^{18} \mathrm{O}\left(\delta^{18} \mathrm{O}_{\mathrm{sw}}\right)$ variations is achieved by paired coral $\mathrm{Sr} / \mathrm{Ca}$ and $\delta^{18} \mathrm{O}$ measurements. The most commonly used method to calculate $\delta^{18} \mathrm{O}_{\mathrm{sw}}$ exploits proxy-SST regressions to convert $\delta^{18} \mathrm{O}$ and $\mathrm{Sr} / \mathrm{Ca}$ to temperature (Gagan et al., 1998; McCulloch et al.,
1994). However, the regressions have generally different intercepts due to different mean values between different coral colonies (e.g. Abram et al., 2009; Felis et al., 2003, 2004). Therefore, omitting the intercept values in order to assess instantaneous changes of $\delta^{18} \mathrm{O}_{\mathrm{sw}}$ is critical (Ren et al., 2003). To do so, the centering method and the combined analytical error are used (Cahyarini et al., 2008). Multitaper Method (MTM) spectral analysis (Ghil et al., 2002), with significance relative to a red noise null hypothesis determined with the robust method of noise background estimation (Mann and Lees, 1996), is applied to the detrended and normalised $\delta^{18} \mathrm{O}_{\mathrm{sw}}$ and instrumental records with the mean annual cycle removed. In correspondence with previous work (Felis et al., 2009; Gagan et al., 1998; Hendy et al., 2002), we term the $\delta^{18} \mathrm{O}_{\mathrm{sw}}$ variations reconstructed from paired coral $\mathrm{Sr} / \mathrm{Ca}$ and $\delta^{18} \mathrm{O}$ measurements coral $\Delta \delta^{18} \mathrm{O}$.

The numerical experiments were performed with the coupled general circulation model COSMOS consisting of the atmospheric model ECHAM5 (Roeckner et al., 2003), ocean model MPIOM (Marsland et al., 2003), and dynamical vegetation model JSBACH (Raddatz et al., 2007). The atmospheric model has a resolution of $\mathrm{T} 31\left(3.75^{\circ} \times 3.75^{\circ}\right)$ in horizontal and 19 vertical hybrid sigma pressure levels. The ocean model has a $3^{\circ} \times 1.8^{\circ}$ averaged horizontal grid with 40 unevenly spaced vertical levels with higher resolution around Greenland and Antarctica (Marsland et al., 2003). We carried out two experiments: a pre-industrial (CTL) experiment and a mid-Holocene one $(6 \mathrm{ka})$, by prescribing the appropriate orbital parameters and greenhouse gases. Details of the model experiments are described in Wei et al. (2012) and Wei and Lohmann (2012).

\section{Results}

\subsection{Modern coral $\delta^{18} \mathrm{O}-\mathrm{SST}$ relationship}

The coral $\delta^{18} \mathrm{O}-\mathrm{SST}$ relationship of the $D$. strigosa colony collected live in Bonaire (BON-0-A) was assessed for the period 1993-2009. The regression equation in reference to gridded monthly SST data (Smith et al., 2008) is

$$
\begin{gathered}
\delta^{18} \mathrm{O}(\% \circ)=-0.106( \pm 0.010) \times \mathrm{SST}-1.432( \pm 0.259) \\
\left(r^{2}=0.41, p<0.01, N=188\right) .
\end{gathered}
$$

Moreover, coral $\delta^{18} \mathrm{O}$ is investigated in reference to local SST data from a nearby island, Curacao (distance $\sim 80 \mathrm{~km}$ ), for a period of 18 months spanning April 1999 to September 2000 (M. J. A. Vermeij, personal communication, 2009). The linear regression for this data is

$$
\begin{gathered}
\delta^{18} \mathrm{O}(\% \circ)=-0.124( \pm 0.016) \times \mathrm{SST}-0.951( \pm 0.437) \\
\left(r^{2}=0.79, p<0.0001, N=18\right) .
\end{gathered}
$$




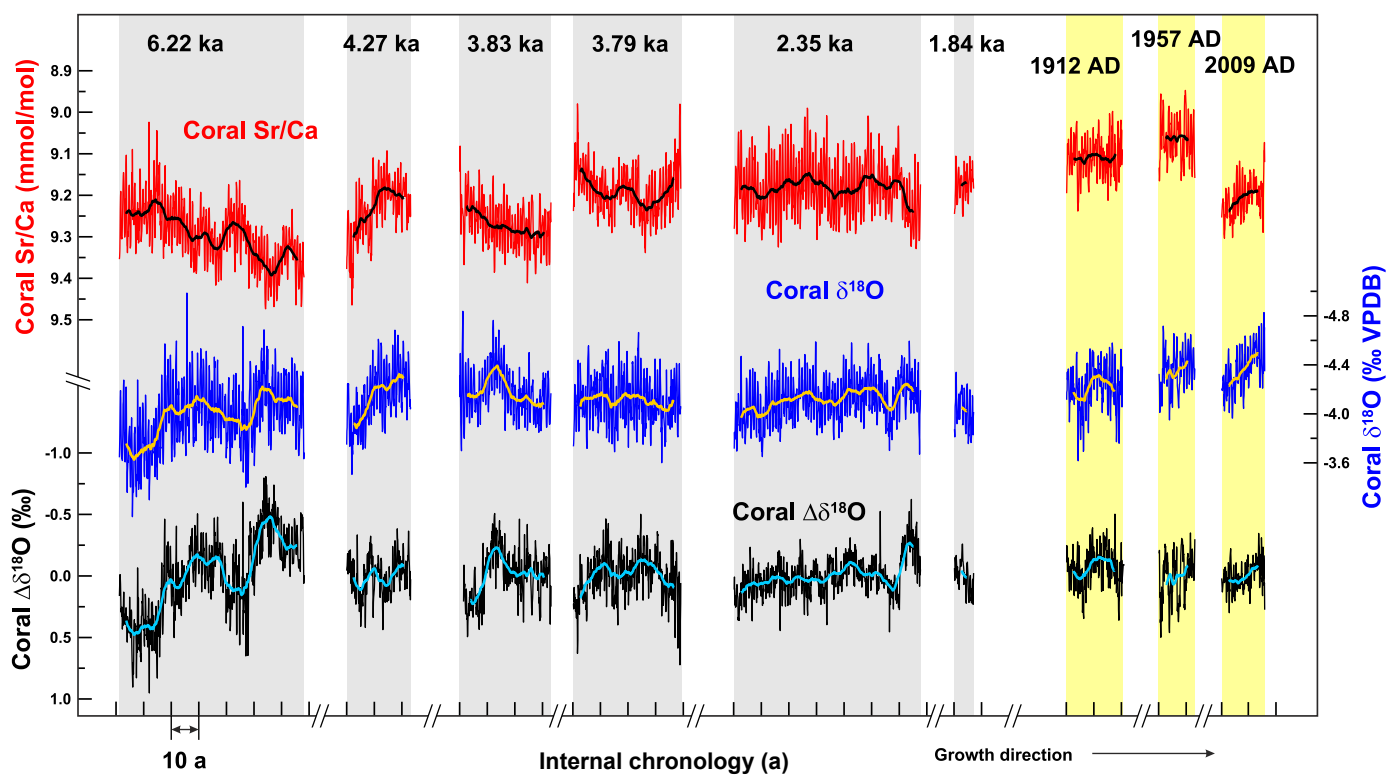

Fig. 2. Monthly resolved coral $\mathrm{Sr} / \mathrm{Ca}$ (red) (Giry et al., 2012), coral $\delta^{18} \mathrm{O}$ (blue) records and derived coral $\Delta \delta^{18} \mathrm{O}$ (black) records of modern (yellow shading) and fossil (grey shading) Diploria strigosa corals from Bonaire and corresponding 5-yr running mean. Coral $\Delta \delta^{18} \mathrm{O}$ records were calculated using the centering method (Cahyarini et al., 2008) and $\mathrm{Sr} / \mathrm{Ca}-\mathrm{SST}$ and $\delta^{18} \mathrm{O}-\mathrm{SST}$ slopes of $-0.061 \mathrm{mmol} \mathrm{mol}^{-1}{ }^{\circ} \mathrm{C}^{-1}$ and $-0.180 \% 0^{\circ} \mathrm{C}^{-1}$ (Corrège, 2006; Gagan et al., 1998), respectively. The U-series ages of the individual coral colonies (Giry et al., 2012) are indicated.

We note that the coral $\delta^{18} \mathrm{O}-\mathrm{SST}$ regression slopes are lower than the published values for $D$. strigosa from Guadeloupe in the eastern Caribbean (Hetzinger et al., 2006). This discrepancy might arise from distinct annual temperature and hydrological cycles between Bonaire and Guadeloupe that in turn affect the amplitude of the oxygen isotopic ratio of coral skeleton at both sites. For instance, Hetzinger et al. (2010) showed that the annual salinity cycle at Guadeloupe decreases when temperature increases. However, at Bonaire such correlation between salinity and temperature is not so straightforward (cf. Sect. 5.2 and Fig. 10), Therefore the regression existing for Bonaire coral $\delta^{18} \mathrm{O}-\mathrm{SST}$ will be different from that of Guadeloupe. Consequently, in order to circumvent uncertainties associated with calibrating proxy data, the reconstructed $\delta^{18} \mathrm{O}_{\mathrm{sw}}$ is derived from a range of proxySST calibrations rather than from fixed calibration values.

\subsection{Surface hydrology changes during the mid- to late Holocene}

Monthly resolved coral $\mathrm{Sr} / \mathrm{Ca}$ and $\operatorname{coral} \delta^{18} \mathrm{O}$ of three modern and six fossil corals are shown in Fig. 2. Each coral record shows clear annual cycles in both $\mathrm{Sr} / \mathrm{Ca}$ and $\delta^{18} \mathrm{O}$, which correlate with the corresponding annual-density bands. Therefore, robust coral internal chronologies could be established, enabling accurate assessment of seasonal to multidecadal variability of coral proxies for well-distributed time windows throughout the mid- to late Holocene.
Mean coral $\Delta \delta^{18} \mathrm{O}$ values for individual colonies were calculated by averaging data of each year and subsequently averaging the resulting annual means of all years constituting the coral record. The mean $\Delta \delta^{18} \mathrm{O}$ values for individual Bonaire corals are shown in Fig. 3. This has been calculated using the coral $\mathrm{Sr} / \mathrm{Ca}-\mathrm{SST}$ and $\delta^{18} \mathrm{O}-\mathrm{SST}$ relationships of $-0.061 \mathrm{mmol} \mathrm{mol}^{-1}{ }^{\circ} \mathrm{C}^{-1}$ (Corrège, 2006) and $-0.180 \% 0^{\circ} \mathrm{C}^{-1}$ (Gagan et al., 1998), respectively, following established procedures (Cahyarini et al., 2008). The three modern corals exhibit between colony offsets in mean $\Delta \delta^{18} \mathrm{O}$. The standard deviation of such intercolony variability is $0.161 \% \circ(1 \sigma)$. The mean $\Delta \delta^{18} \mathrm{O}$ values of all corals suggest a trend towards more positive values over the last $6.2 \mathrm{ka}$ (Fig. 3). This tendency in the coral data does not change when a range of proxy-SST relationships is used (Table S1 in the Supplement). Since modern intercolony variability in mean coral $\Delta \delta^{18} \mathrm{O}$ is large, and equivalent to $\sim 1.6 \mathrm{psu}(2 \sigma)$ using the $\delta^{18} \mathrm{O}_{\mathrm{sw}}$-salinity relationship of Watanabe et al. (2001) for modern Caribbean surface waters, quantification of mean $\Delta \delta^{18} \mathrm{O}$ in terms of SSS for past time intervals is not further considered.

\subsection{Seasonal changes in coral $\Delta \delta^{18} \mathrm{O}$}

\subsubsection{Insights from raw data}

The seasonality is defined as the difference between maximum and minimum monthly values of a given year that is then averaged for all years constituting the record. The coral 


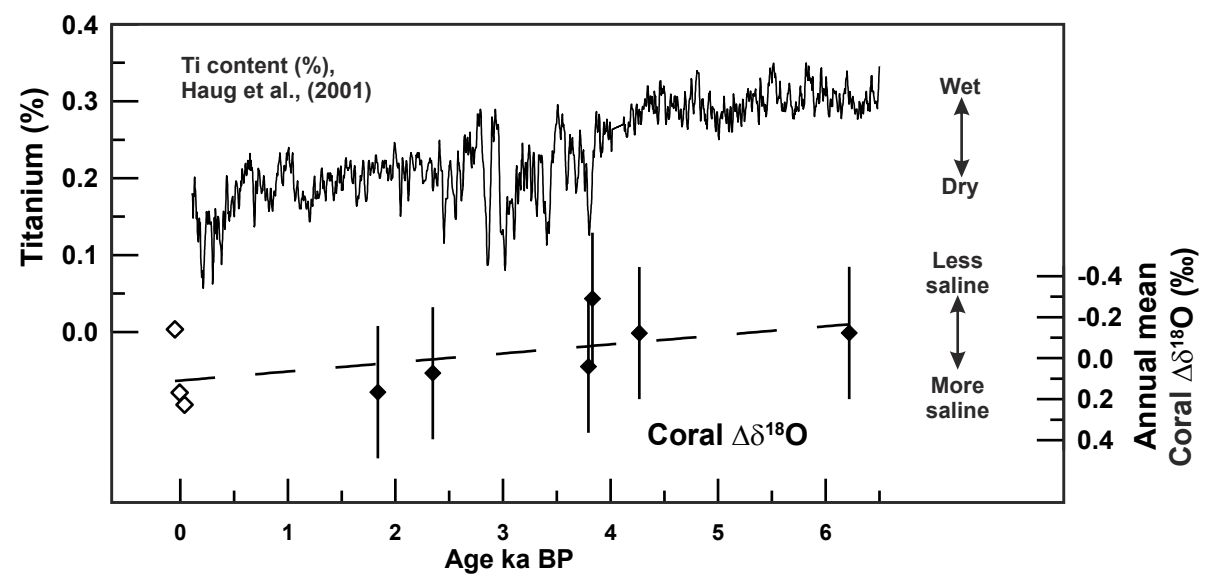

Fig. 3. Comparison between mean coral $\Delta \delta^{18} \mathrm{O}$ and Cariaco Basin Ti record (Haug et al., 2001). Coral $\Delta \delta^{18} \mathrm{O}$ has been calculated for individual records using established procedures (Cahyarini et al., 2008; Corrège, 2006; Gagan et al., 1998). Error bars are the combined error (root of the sum of the squares) of the standard deviation $(2 \sigma)$ from mean coral $\Delta \delta^{18} \mathrm{O}$ of three modern Diploria strigosa and the standard error ( $2 \mathrm{SE}$ ) of the mean coral $\Delta \delta^{18} \mathrm{O}$ value for individual corals, following established procedure (Abram et al., 2009) but applied to reconstructed coral $\Delta \delta^{18} \mathrm{O}$. Note that coral $\Delta \delta^{18} \mathrm{O}$ records indicate a trend toward more saline conditions during the mid- to late Holocene that might be linked to more precipitation at $6 \mathrm{ka}$.

$\delta^{18} \mathrm{O}$ records of three modern corals indicate a mean $\delta^{18} \mathrm{O}$ seasonality of $0.440 \pm 0.047 \%$ o $(1 \sigma)$ ranging from 0.400 to $0.491 \%$ (Fig. 4). It is assumed that the between-colony differences in coral $\delta^{18} \mathrm{O}$ seasonality do not result from changing environmental conditions over the last century, but rather reflect coral growth processes (e.g. Gagan et al., 1998). Therefore, the combined error (Abram et al., 2009) that takes into account modern between-colony offsets in coral $\delta^{18} \mathrm{O}$ seasonality (Giry et al., 2012) is considered for our estimates of Holocene coral $\delta^{18} \mathrm{O}$ seasonality. Considering this uncertainty, most of the fossil coral records show $\delta^{18} \mathrm{O}$ seasonality that is not significantly different from that given by three modern corals. However, significantly increased $\delta^{18} \mathrm{O}$ seasonality $(0.622 \pm 0.098 \%$ o $)$ is observed in the $6.22 \mathrm{ka}$ coral (Fig. 4).

Composite annual $\mathrm{Sr} / \mathrm{Ca}$ and $\delta^{18} \mathrm{O}$ cycles derived from monthly resolved records of individual corals reveal clear annual cycles for both modern and fossil colonies (Fig. 5a). Therefore, changes in the timing between both proxies are assessed for the annual cycle (Fig. 5b). Cross-spectral analyses between measured coral proxies reveal that coral $\delta^{18} \mathrm{O}$ annual cycles lead corresponding coral $\mathrm{Sr} / \mathrm{Ca}$ cycles by about a month in modern colonies. The phase angle for modern coral records indicates very similar values, showing good reproducibility among modern colonies. Annual $\mathrm{Sr} / \mathrm{Ca}$ and $\delta^{18} \mathrm{O}$ cycles from fossil corals indicate different patterns in the past. For instance, most of the fossil corals reveal that coral $\mathrm{Sr} / \mathrm{Ca}$ either leads or is in phase with coral $\delta^{18} \mathrm{O}$ (Fig. 5b). However, the $6.22 \mathrm{ka}$ coral indicates that $\delta^{18} \mathrm{O}$ leads $\mathrm{Sr} / \mathrm{Ca}$ changes, by 0.3 month (Fig. $5 \mathrm{~b}$ ), all of which provide evidence for changes in the seasonality of the hydrological cycle throughout the mid- to late Holocene.

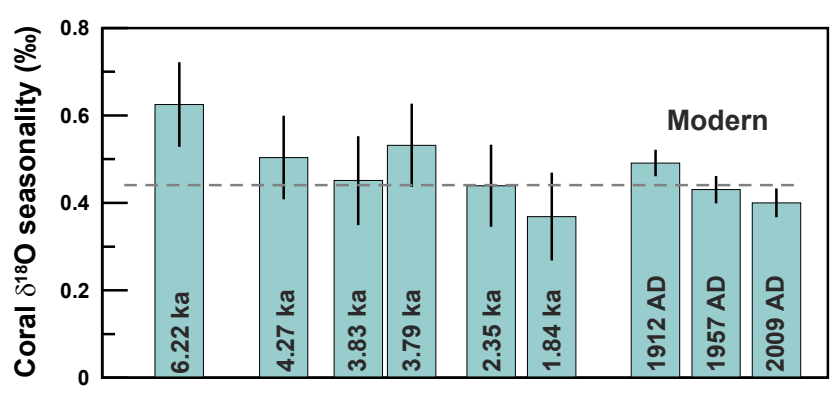

Fig. 4. Coral $\delta^{18} \mathrm{O}$ seasonality calculated for individual Bonaire coral records. Dashed line represents the mean modern $\delta^{18} \mathrm{O}$ seasonality $(0.440 \%$ ) calculated from the mean seasonality of the three modern corals. Error bars for fossil corals are the combined error (root of the sum of the squares) of the standard deviation $(2 \sigma)$ from mean $\delta^{18} \mathrm{O}$ seasonality of three modern Diploria strigosa and the standard error ( $2 \mathrm{SE}$ ) of the averaged $\delta^{18} \mathrm{O}$ seasonality measurements for individual coral records, following established procedures (Abram et al., 2009) but applied to reconstructed seasonality. Error bars for modern corals are $2 \mathrm{SE}$. Note that the $6.22 \mathrm{ka}$ coral shows significantly increased $\delta^{18} \mathrm{O}$ seasonality compared to that given by three modern corals.

\subsubsection{Insights from calculated coral $\Delta \delta^{18} \mathrm{O}$}

Composite annual coral $\Delta \delta^{18} \mathrm{O}$ cycles were calculated for individual coral records using a range of proxy-SST calibrations. This is used in order to test the impact of varying calibrations on the reconstructed $\Delta \delta^{18} \mathrm{O}$ (Fig. S1 in the Supplement). Annual $\Delta \delta^{18} \mathrm{O}$ cycles calculated using calibrations from Hetzinger et al. (2006) are very different in amplitude and timing from that given by a set of four other calibrations, including local calibrations (Giry et al., 2012, this 

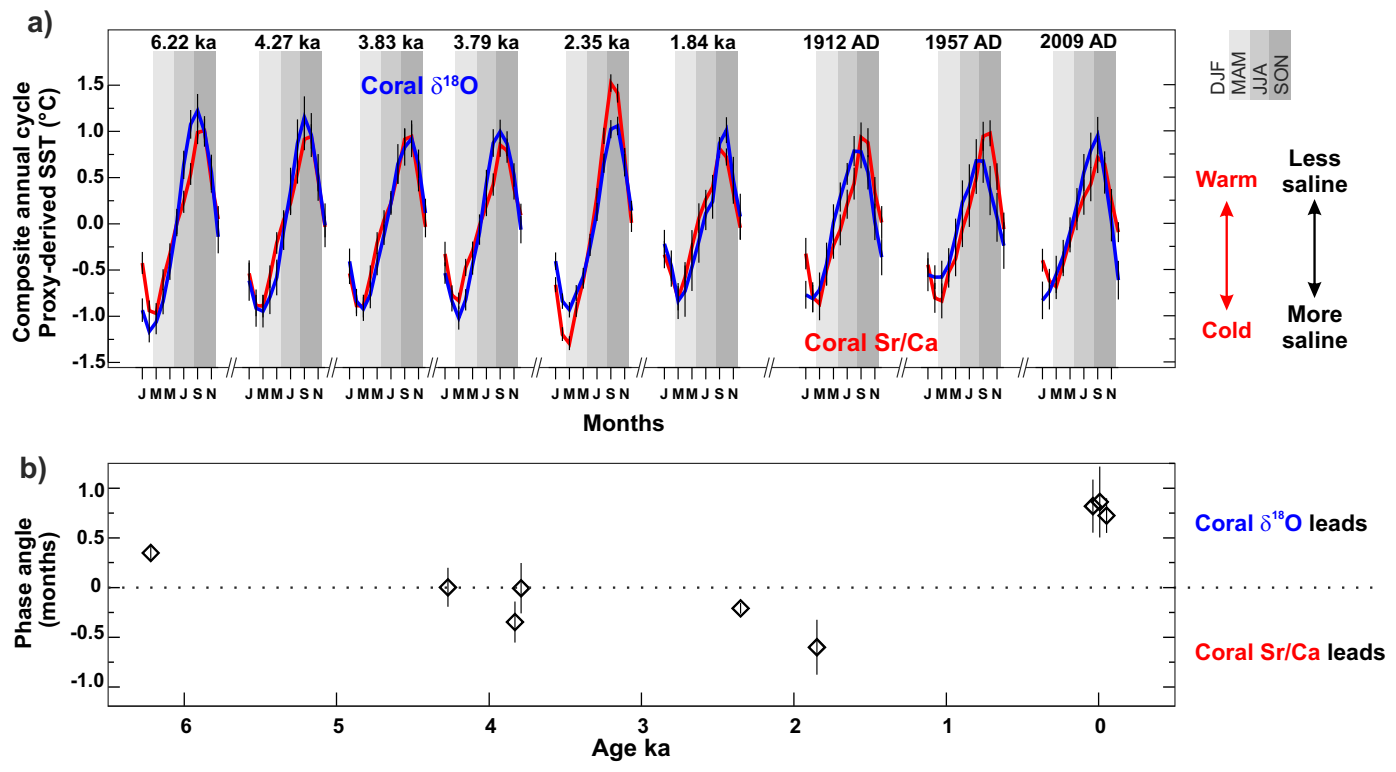

Fig. 5. (a) Composite annual cycles of coral $\mathrm{Sr} / \mathrm{Ca}$ and $\delta^{18} \mathrm{O}$ for each coral record used in this study converted in degree Celsius by using $\mathrm{Sr} / \mathrm{Ca}$-SST and $\delta^{18} \mathrm{O}-\mathrm{SST}$ relationships of $-0.061 \mathrm{mmol} \mathrm{mol}^{-1}{ }^{\circ} \mathrm{C}^{-1}$ and $-0.180 \%{ }^{\circ} \mathrm{C}^{-1}$ (Corrège, 2006; Gagan et al., 1998). Error bars indicate the standard error of the mean calculated for individual months. (b) Phase angles of the annual cycles estimated by cross-spectral analyses between monthly coral $\mathrm{Sr} / \mathrm{Ca}$ and coral $\delta^{18} \mathrm{O}$ time series. Error bars indicate the $80 \%$ confidence interval.

study). Since the amplitude of the annual $\Delta \delta^{18} \mathrm{O}$ cycle given by our local calibrations provide reasonably good estimates of the real Caribbean annual $\delta^{18} \mathrm{O}_{\text {sw }}$ cycle (Watanabe et al., 2001), we rely on well-established coral proxy-SST calibrations (Corrège, 2006; Gagan et al., 1998) for the interpretation of our fossil coral records. The combined analytical uncertainties for reconstructing $\Delta \delta^{18} \mathrm{O}$ using the $\mathrm{Sr} / \mathrm{Ca}-\mathrm{SST}$ relationship of $-0.061 \mathrm{mmol} \mathrm{mol}^{-1}{ }^{\circ} \mathrm{C}^{-1}$ (Corrège, 2006) and the $\delta^{18} \mathrm{O}-\mathrm{SST}$ relationship of $-0.18 \%{ }^{\circ} \mathrm{C}^{-1}$ (Gagan et al., $1998)$ is $\pm 0.077 \%$ o $(1 \sigma)$. Consequently, coral $\Delta \delta^{18} \mathrm{O}$ variability with amplitude greater than $0.154 \%$ were considered significant with respect to analytical uncertainty (Cahyarini et al., 2008). Assuming that the above calibrations (Corrège, 2006; Gagan et al., 1998) are the most representative, the composite annual $\delta^{18} \mathrm{O}_{\mathrm{sw}}$ cycles from three modern corals indicate lower values in spring and summer and higher values in fall and winter with average amplitude of $0.157 \%$ (Fig. 6). Since the composite annual cycles are derived from multiple years constituting the record, their timing is reliable, although the reconstructed amplitude appears insignificant in some records. The reconstructions of coral $\Delta \delta^{18} \mathrm{O}$ indicate a similar seasonal hydrological regime (e.g. low/high coral $\Delta \delta^{18} \mathrm{O}_{\text {sw }}$ values in summer/winter) at $6.22,4.27$ and $3.79 \mathrm{ka}$, whereas distinct regimes are observed at 3.83, 2.35 and $1.84 \mathrm{ka}$. The $6.22 \mathrm{ka}$ coral record reveals increased coral $\Delta \delta^{18} \mathrm{O}$ seasonality with amplitude of $0.193 \%$ o that is $23 \%$ greater than the amplitude of the modern annual $\Delta \delta^{18} \mathrm{O}$ cycle given by three modern corals. Moreover, a period of reversed seasonality of the hydrological cycle is detected at $2.35 \mathrm{ka} \mathrm{BP}$. This record indicates more positive values in summer and more negative values in winter. The deviation from the mean $\Delta \delta^{18} \mathrm{O}$ value is investigated for individual months in each coral record (Fig. 6). It is found that greatest deviation from the mean occurs in fall and winter in the three modern corals. Although this pattern is fuzzy in the Holocene corals, the $6.22 \mathrm{ka}$ coral record indicates that the greatest negative and positive deviation from the mean value occurs during both summer and winter seasons, respectively.

\subsection{Interannual to multidecadal coral $\Delta \delta^{18} \mathrm{O}$ variability}

The MTM spectral analysis of monthly coral $\Delta \delta^{18} \mathrm{O}$ records indicates significant quasi-biennial and interannual variability that is often superimposed on inter- to multidecadal scale variability (Fig. 7). Significant spectral peaks in the quasibiennial band (defined here as $<2.3 \mathrm{yr}$ ) are detected in most coral records. Interannual ( 2.3 to $7 \mathrm{yr}$ ), near-decadal ( 7 to $15 \mathrm{yr}$ ) as well as inter- to multidecadal (15 to $40 \mathrm{yr}$ ) variability of coral $\Delta \delta^{18} \mathrm{O}$ are identified in most of the coral records. Instrumental rainfall data (Hulme et al., 1998) reveal that precipitation over Bonaire is also characterised by significant quasi-biennial and interannual spectral peaks (Fig. 7), whereas inter- to multidecadal variability of Bonaire precipitation is not significant over the period 1930-1999. Furthermore, while interannual variability seems to be a prominent feature of the coral $\Delta \delta^{18} \mathrm{O}$ records, the coral record at $2.35 \mathrm{ka}$ indicates enhanced spectral power at interannual periodicities centred at $6.1 \mathrm{yr}$ and the $6.22 \mathrm{ka}$ coral reveals pronounced variability at $7.8 \mathrm{yr}$. Moreover, inter- to multidecadal variability seems to be a prominent feature in the Holocene 

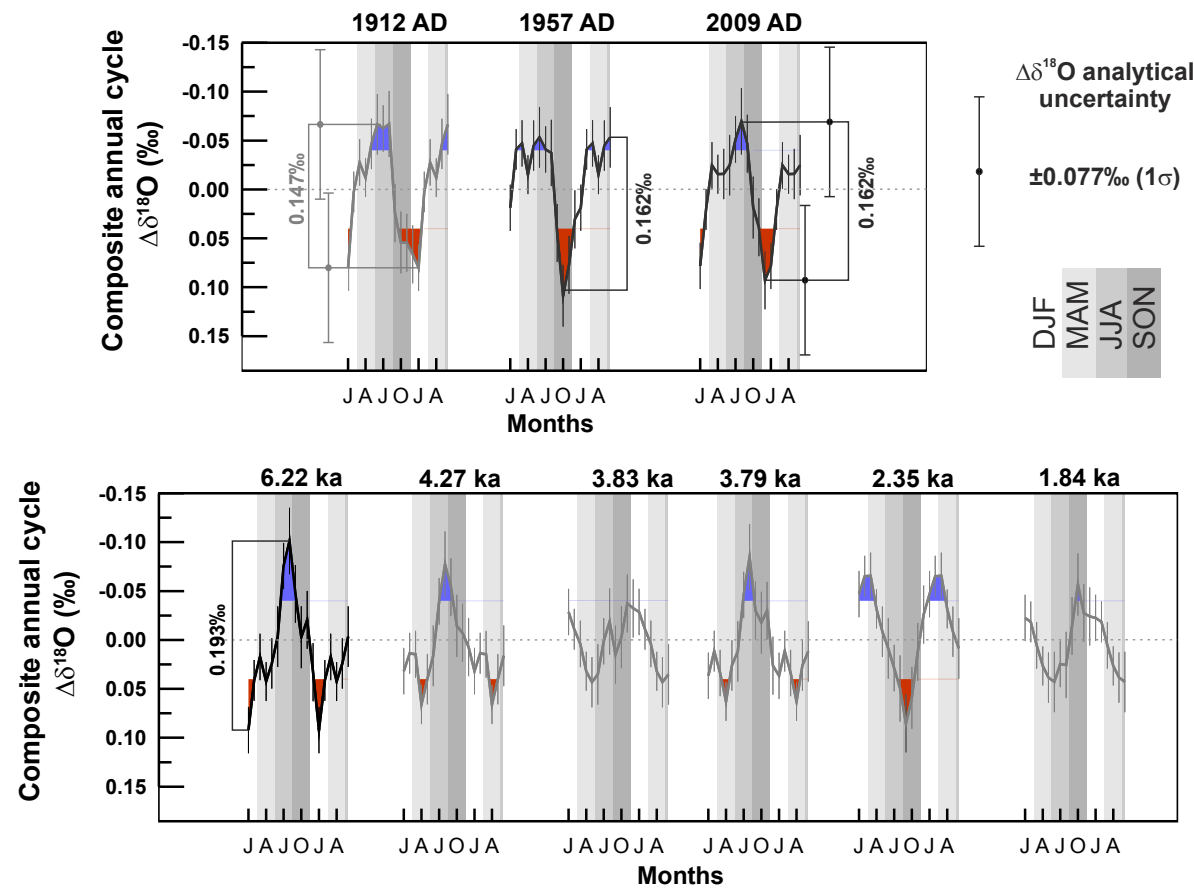

Fig. 6. Composite annual coral $\Delta \delta^{18} \mathrm{O}$ cycles for three modern (top panel) and six fossil (bottom panel) corals calculated using the centering method (Cahyarini et al., 2008) and Sr/Ca-SST and $\delta^{18} \mathrm{O}-\mathrm{SST}$ relationships of $-0.061 \mathrm{mmol} \mathrm{mol}{ }^{-1}{ }^{\circ} \mathrm{C}^{-1}$ and $-0.180 \%{ }^{\circ} \mathrm{C}^{-1}(\mathrm{Corrège}$, 2006; Gagan et al., 1998). Combined analytical uncertainty is $0.154 \%$ o $(2 \sigma)$. Composite annual cycles represented in black (gray) are characterised by an amplitude of the annual $\Delta \delta^{18}$ O cycle higher (lower) than $2 \sigma$. Vertical gray shading indicates seasons: winter (DecemberFebruary, DJF), spring (March-May, MAM), summer (June-August, JJA) and fall (September-November, SON). Negative and positive deviations from the mean value greater than $0.4 \%$ are indicated by blue and red colours, respectively.

coral $\Delta \delta^{18} \mathrm{O}$ records. These periodicities are, however, at the limit of detection with respect to the length of the considered time series, where oscillatory behaviour becomes indistinguishable from a secular trend. Nevertheless, the $6.22 \mathrm{ka}$ coral record indicates enhanced spectral power in this band that is unprecedented in any other coral records.

The magnitude of $\Delta \delta^{18} \mathrm{O}$ changes throughout the mid- to late Holocene is further investigated for different timescales. Individual coral $\Delta \delta^{18} \mathrm{O}$ records have been filtered with a Gaussian bandpass filter (Paillard et al., 1996) to isolate quasi-biennial $(<2.3 \mathrm{yr})$, interannual $(2.3$ to $7 \mathrm{yr})$, neardecadal (7 to $15 \mathrm{yr}$ ) and inter- to multidecadal (15 to $40 \mathrm{yr}$ ) components of variability (Fig. 8). The amplitude of the quasi-biennial, interannual, and near-decadal coral $\Delta \delta^{18} \mathrm{O}$ variability has not notably changed throughout the mid- to late Holocene compared to that of the inter- to multidecadal band. Interestingly, the standard deviation of the 15 to $40 \mathrm{yr}$ bandpass-filtered time series of the $6.22 \mathrm{ka}$ coral $\Delta \delta^{18} \mathrm{O}$ record is twice as large as the average variance given by all coral records (Fig. 8).

\subsection{Correlation between coral $\Delta \delta^{18} \mathrm{O}$ and $\mathrm{Sr} / \mathrm{Ca}$-SST}

The correlation between $\mathrm{Sr} / \mathrm{Ca}$-derived SST and $\Delta \delta^{18} \mathrm{O}$ related salinity is investigated for quasi-biennial, interannual, near-decadal, and inter- to multidecadal timescales (Fig. 9) by using the corresponding filtered time series. Coral data indicate that warmer than average SSTs are characterised by more saline conditions and vice versa. The correlation coefficient is positive for all investigated timescales. The correlation coefficients between filtered time series are greater than 0.5 in most of the records, suggesting that the observed relationship between SST and $\Delta \delta^{18} \mathrm{O}$ was prominent in the southern Caribbean Sea over the last $6.2 \mathrm{ka}$. To investigate the effect of different calibration values on the sign of the correlation, $\Delta \delta^{18} \mathrm{O}$ records derived from a range of proxy-SST calibrations (i.e. Hetzinger et al., 2006) were used. However, different calibration values do not affect the sign of the correlation between $\mathrm{Sr} / \mathrm{Ca}$-derived SST and $\Delta \delta^{18} \mathrm{O}$-related salinity (not shown).

\section{Discussion}

\subsection{Mean $\delta^{18} \mathrm{O}_{\mathrm{sw}}$ changes over the last $6.2 \mathrm{ka}$}

During the early and mid-Holocene, mid-latitudes of the northern Hemisphere were characterized by greater insolation in summer compared to today, and proxy reconstructions showed that the ITCZ was located further to the north at that time, thus enhancing precipitation in more northern 
a)
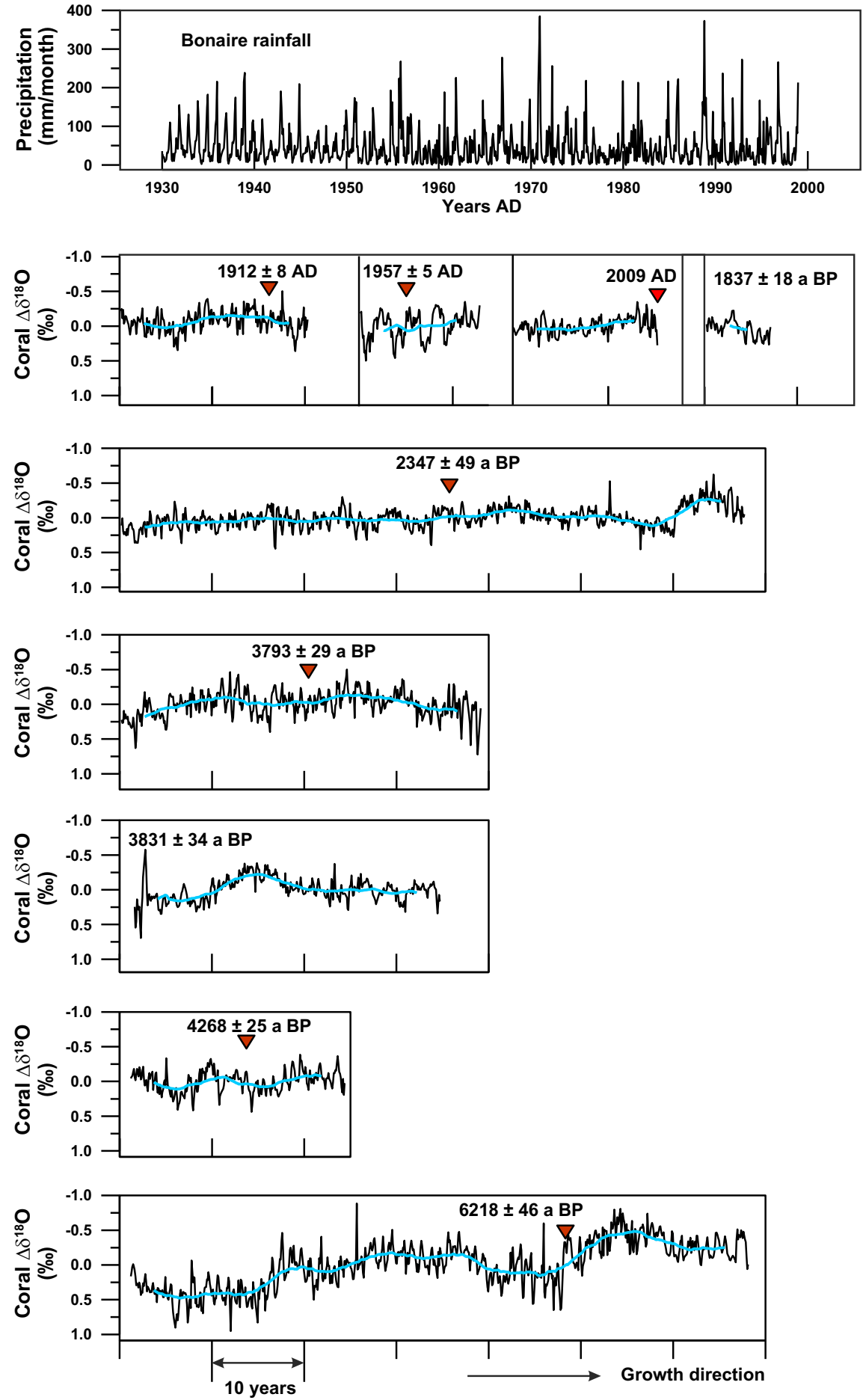

b)
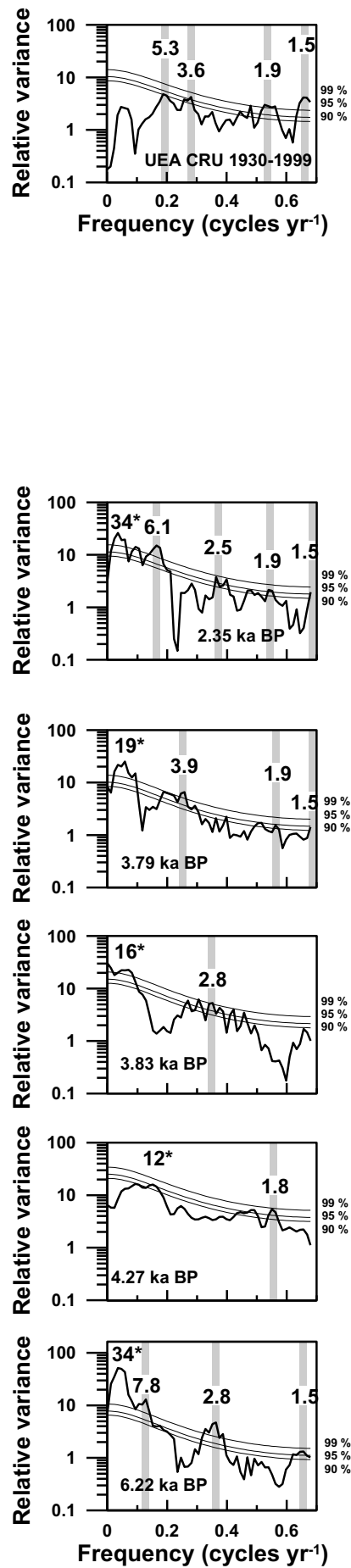

Fig. 7. (a) Monthly rainfall record from gridbox centred on Bonaire $\left(12.5^{\circ} \mathrm{N} ; 67.5^{\circ} \mathrm{W}\right.$ ) (top panel) (Hulme et al., 1998) and monthly reconstructed coral $\Delta \delta^{18} \mathrm{O}$ records from Bonaire corals calculated using the centering method (Cahyarini et al., 2008). Thick blue lines represent the 5-yr running average. Sr/Ca-SST and $\delta^{18} \mathrm{O}-\mathrm{SST}$ regression coefficients used are -0.061 and $-0.180 \mathrm{mmol} \mathrm{mol}{ }^{-1}{ }^{\circ} \mathrm{C}^{-1}$, respectively. U-series ages of fossil corals (Giry et al., 2012) are indicated. (b) Multitaper method (MTM) spectral analysis (significance relative to a red noise null hypothesis determined with the robust method of noise background estimation; Ghil et al., 2002; Mann and Lees, 1996; number of tapers 3 ; bandwidth parameter 2) of detrended and normalised monthly precipitation and coral $\Delta \delta^{18} \mathrm{O}$ records with length $>20 \mathrm{yr}$ where the mean annual cycle has been removed. Ninety (90), 95, and $99 \%$ confidence levels are indicated. Significant spectral peaks are labelled. Asterisks indicate periodicities at the limit of detection with respect to the length of the time series, where oscillatory behaviour becomes indistinguishable from a secular trend. 

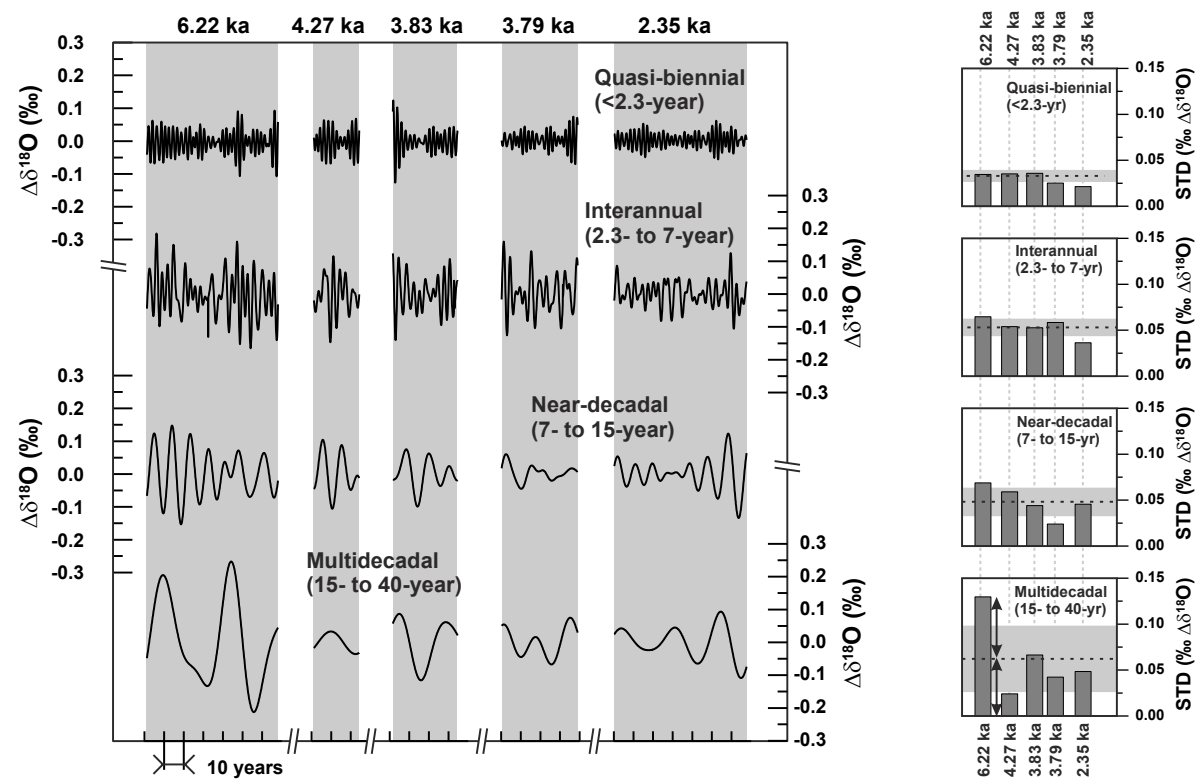

Fig. 8. Quasi-biennial, interannual, near-decadal and multidecadal Gaussian bandpass-filtered time series for individual coral $\Delta \delta^{18} \mathrm{O}$ records (from Fig. 7) with length $>20 \mathrm{yr}$ (left panel) and the corresponding standard deviations of filtered time series (right panels). Horizontal dashed lines and grey areas indicate the mean standard deviations (STD) of the filtered time series and the corresponding $2 \sigma$, respectively. Black arrows indicate that the variance of the multidecadal bandpass-filtered time series of the $6.2 \mathrm{ka}$ coral $\Delta \delta^{18} \mathrm{O}$ record is twice as large as given by the corresponding mean standard deviation of all coral records.

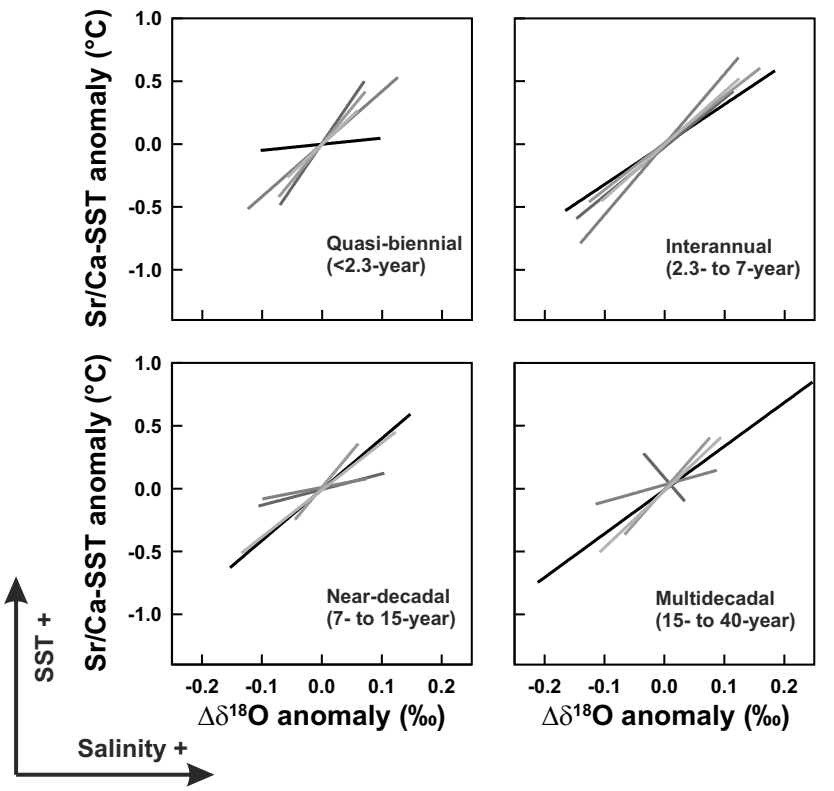

Fig. 9. Linear regressions between Gaussian bandpass-filtered coral $\Delta \delta^{18} \mathrm{O}$ and $\mathrm{Sr} / \mathrm{Ca}-\mathrm{SST}$ time series for Bonaire coral records with length $>20 \mathrm{yr}$ as calculated after Corrège (2006) and Gagan et al. (1998). Note that for all investigated timescales, most coral records indicate positive correlation coefficients which suggest that periods of warmer than average sea surface temperatures (SST) are characterised by more saline conditions and vice versa. latitudes of the tropical Atlantic (Fleitmann et al., 2003; Haug et al., 2001; Hodell et al., 1991). In line with this, our coral $\Delta \delta^{18} \mathrm{O}$ records indicate a trend from the mid- toward the late Holocene (Fig. 3), suggesting that the hydrological balance of the Southern Caribbean shifted from less saline in the mid-Holocene towards more saline conditions today. However, this trend is not significant, possibly due to the combined effect of different vital effects between coral colonies (Giry et al., 2012) and rapid shifts of the regional hydrological conditions (Haug et al., 2001). Although accurate quantification of changes in mean $\delta^{18} \mathrm{O}_{\mathrm{sw}}$ is difficult to infer from our coral records, the increase of $\delta^{18} \mathrm{O}_{\mathrm{sw}}$ over the last $6.2 \mathrm{ka}$ did not exceed $0.322 \%$ o ( $2 \sigma$ given by three modern corals) which would correspond to a salinity increase of $<1.6$ psu according to Watanabe et al. (2001). In line with this, numerical simulations integrating an isotopic module (Oppo et al., 2007) indicated lighter Caribbean $\delta^{18} \mathrm{O}_{\mathrm{sw}}$ during the mid-Holocene that is linked to a reduced Atlantic to Pacific water transport.

\subsection{Today's hydrological cycle and advection of fresh water}

The composite annual $\Delta \delta^{18} \mathrm{O}$ cycles derived from modern corals revealed lower values in spring and summer and higher values in fall and winter (Figs. 6 and 10). Climatological data from the World Ocean Atlas 09 (Antonov et al., 2010) indicate SSS seasonality near Bonaire of $\sim 1.2$ psu with maximum and minimum SSS values occurring in May and 

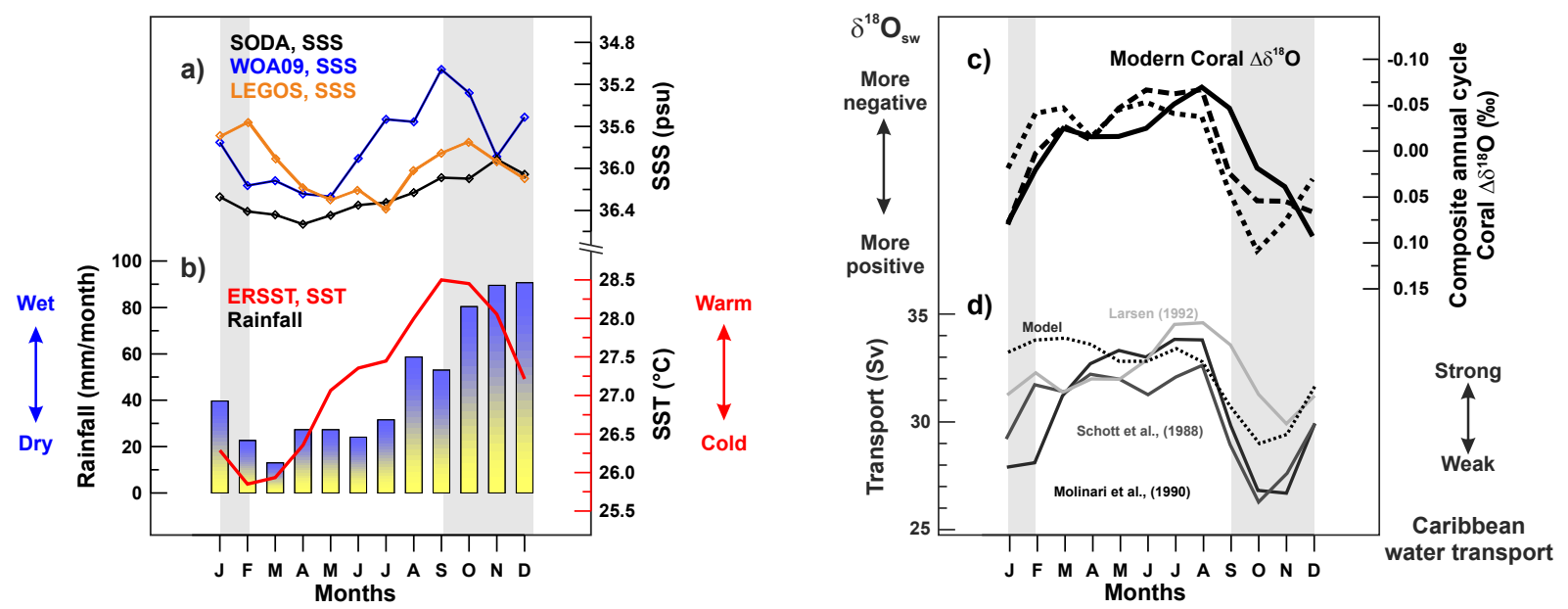

Fig. 10. Left panel: monthly mean climatology of environmental parameters at the study site, Bonaire. (a) Composite annual sea surface salinity (SSS) cycles from World Ocean Atlas 09 (Antonov et al., 2010) in a $1^{\circ} \times 1^{\circ}$ gridbox (blue), from CARTON-GIESE SODA v2p0p24 (Carton and Giese, 2008) in a $0.5^{\circ} \times 0.5^{\circ}$ gridbox (black) and from Sea Surface Salinity Observation Service (Reverdin et al., 2007) in a $1^{\circ} \times 1^{\circ}$ gridbox (orange); (b) sea surface temperature (SST) monthly climatology for 1970-2000 from ERSSTv3b (Smith et al., 2008) in a $2^{\circ} \times 2^{\circ}$ gridbox (red line) and climatology of monthly mean precipitation for the same period from UEA CRU Hulme Global prcp in a gridbox centred at 67.5 and $12.5^{\circ}$ (Hulme et al., 1998) (vertical bars). Right panels: (c) composite annual coral $\Delta \delta^{18} \mathrm{O}$ cycle of three modern corals, 1912 AD (dashed line), 1957 AD (dotted line) and 2009 AD (solid line) calculated as previously described (cf. Fig. 6); (d) modelled (black dashed line) and observed annual cycle of the Florida Current (modified from Johns et al., 2002).

September, respectively. However, according to SODA salinity (Simple Ocean Data Assimilation Reanalysis) (Carton and Giese, 2008), the seasonal cycle for Bonaire is $\sim 0.6 \mathrm{psu}$ in amplitude with maximum and minimum SSS values occurring in April and November, respectively (Fig. 10). Moreover, together with a lack of local salinity data, these datasets and others (Reverdin et al., 2007) indicate that there is no consensus on the real amplitude and timing of the annual salinity cycle around Bonaire. Since Bonaire's climate is characterized by high evaporation rate and low annual rainfall with the rainy season lagging maximum SST by a month, local rainfall cannot explain the phase lag between coral $\delta^{18} \mathrm{O}$ and $\mathrm{Sr} / \mathrm{Ca}$ as inferred from the modern corals (Fig. 6). Consequently, alternate mechanisms are proposed for explaining the modern freshwater budget of the region as documented in Bonaire corals.

The freshwater budget in the Caribbean is influenced by both the evaporation and precipitation over the basin (Etter et al., 1987) and freshwater transported from the Amazon and Orinoco rivers by surface currents to the Caribbean (Hellweger and Gordon, 2002). The period of strongest evaporation occurs in wintertime (Etter et al., 1987; Giannini et al., 2000; Hastenrath and Lamb, 1978) and the lowest in summertime. Therefore, the annual $\Delta \delta^{18} \mathrm{O}$ cycle inferred from modern corals could be partially explained by seasonal changes in the local freshwater flux over the Caribbean. The Caribbean Current (CC) is the dominant surface current in the Caribbean, transporting warm and fresh surface water northwestward from the southeastern part of the basin to the Gulf of Mexico (Wüst, 1964) (Fig. 1). The outflow of this warm water mass concentrates in the Florida Strait, contributing to the Gulf Stream and the Western Boundary Current. The highest surface velocity of the CC (exceeding $100 \mathrm{~cm} \mathrm{~s}^{-1}$ ) occurs near the southern boundary along the coast of Venezuela and the Netherlands Antilles (Fratantoni, 2001; Hernández et al., 2000) suggesting that Bonaire is highly sensitive to changes in surface water transport by the CC. Water masses transported through the Caribbean originate from the North Brazilian Current (NBC) and the Guyana Current (GC), which transport South Atlantic waters and fresh, isotopically light waters discharged from the Amazon River into the Caribbean (Chérubin and Richardson, 2007; LeGrande and Schmidt, 2006; Hellweger and Gordon, 2002) (Fig. 1). The flow through the Caribbean displays a seasonal cycle that is strongest in the far southeastern Caribbean through the Windward Islands passages (Johns et al., 2002). Moreover, this inflow is intimately linked to the outflow through the Florida Current (Johns et al., 2002). The Florida Current indicates strong seasonality in surface water transport through the Florida Strait (Johns et al., 2002; Larsen, 1992; Molinari et al., 1990; Schott et al., 1988) (Fig. 10). The outflow from the Caribbean shows maximum transport in spring and summer and minimum in fall. From spring to summer, maximum transport appears to result from a strengthened NBC and GC primarily driven by changes in seasonal winds (Johns et al., 2002; Müller-Karger et al., 1989). The reduction of Atlantic inflow into the Caribbean in the second half of the year is thought to be linked to a weakened NBC and GC that redirect fresher tropical Atlantic water eastward at this time (Johns et al., 2002). Consequently, 
the annual $\Delta \delta^{18} \mathrm{O}$ cycle of our modern Bonaire corals can also reflect the annual cycle of fresher and isotopically light water transported by the western boundary flow into the Caribbean.

\subsection{Mid-Holocene: enhanced precipitation in summer}

The mid-Holocene coral indicates significantly increased seasonality of the hydrological cycle at $6.2 \mathrm{ka}$ as inferred from both the measured coral $\delta^{18} \mathrm{O}$ (Figs. 4 and 5) and the reconstructed coral $\Delta \delta^{18} \mathrm{O}$ records (Fig. 6). The composite annual $\Delta \delta^{18} \mathrm{O}$ cycle of the mid-Holocene coral indicates lowest and highest values in August and January, respectively. The large uncertainties for estimating mean $\Delta \delta^{18} \mathrm{O}$ conditions (cf. Sect. 4.2) along with differences in the offset between mean coral $\mathrm{Sr} / \mathrm{Ca}$ and $\delta^{18} \mathrm{O}$ among individual colonies do not allow us to conclude whether this increased seasonality is due to enhanced precipitation in summer and/or increased evaporation in winter. Nevertheless, the magnitude and timing of this annual $\Delta \delta^{18} \mathrm{O}$ cycle are further investigated. Periods of the year characterised by deviation from the mean greater than $0.4 \%$ (standard choice) are displayed in Fig. 6 . The annual $\Delta \delta^{18} \mathrm{O}$ cycle documented in the mid-Holocene coral indicates that significant deviations occur during both summer and winter seasons. However, the negative deviation from the mean during summer months is unprecedented in this record. The sharp transition from more positive to more negative values seems to occur within less than two months. This sharp summer peak occurring in June-July is typical for a transition from more to less saline conditions that could be linked to enhanced convective activity at that time.

Our sub-seasonally resolved $6.22 \mathrm{ka}$ coral record indicates that the large deviation towards more negative $\delta^{18} \mathrm{O}_{\mathrm{sw}}$ values documented in summer provides strong support for intense summer precipitation in the southern Caribbean Sea, which is possibly brought by a more northern position of the ITCZ. This interpretation is consistent with other reconstructions of hydrological conditions in the Caribbean region that showed that the ITCZ was located further to the north during the mid-Holocene (Haug et al., 2001; Hodell et al., 1991). In line with this, our simulations using the coupled general circulation model COSMOS (Wei et al., 2012) indicate more humid conditions in the Caribbean during the mid-Holocene due to more precipitation (Fig. 11b, blue colour). The annual hydrological cycle inferred from the model simulation suggests that more summer precipitation contributed to the increased annual hydrological cycle over the Caribbean at 6 ka BP (Fig. 11a).

The regional SSS in the Caribbean is affected by both the ocean currents and local $P-E$. The ocean currents transport relatively fresh water from southward locations which are under the influence of the Amazon and Orinoco rivers. In the area off the coast of northern South America, the model is not suitable to resolve all regional details. However, we can detect two main features. Along the coast where the
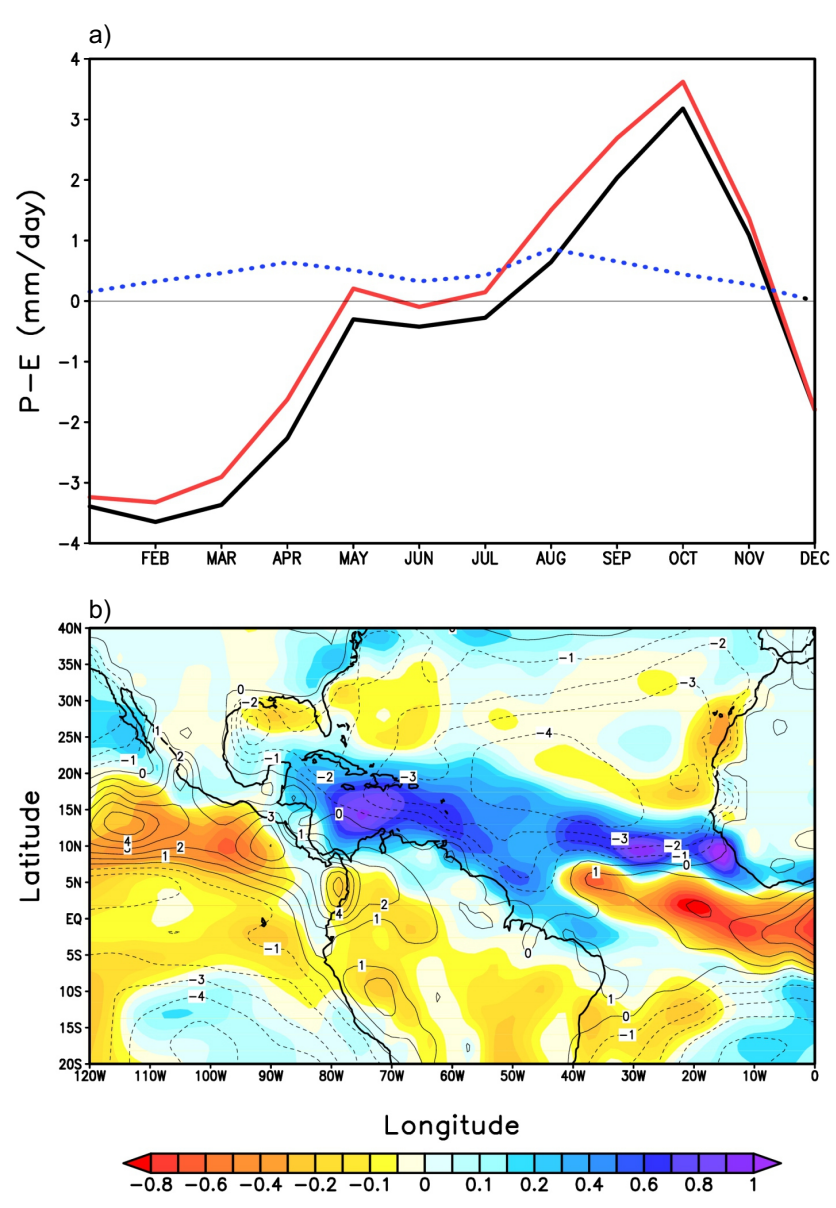

Fig. 11. Precipitation minus Evaporation $(P-E)$ anomaly $\left(\mathrm{mm} \mathrm{day}^{-1}\right)$ at $6 \mathrm{ka} \mathrm{BP}$ inferred from numerical simulations with the coupled general circulation model COSMOS. (a) Normalised annual cycle of $P-E\left(\mathrm{~mm} \mathrm{day}^{-1}\right)$ for Pre-Industrial (PI) times (black), $6 \mathrm{ka}$ (red) and their difference (blue dotted) averaged over the area of $65-83^{\circ} \mathrm{W}, 10-20^{\circ} \mathrm{N}$. (b) Annual mean $P-E$ for PI (contour) and for $6 \mathrm{ka}$ anomalies relative to PI (shaded).

freshwater from Columbian and Venezuelan rivers (including the Orinoco) enters the sea (Fig. 12), SSS is reduced for $6 \mathrm{ka}$, whereas offshore SSS is increased, mainly for the boreal spring season (not shown). The model simulation indicates that easterlies get weakened at $6 \mathrm{ka}$ by about $10 \%$, resulting in slower ocean currents and less import of freshwater from the south, especially from the Amazon, into the Caribbean. Consequently, the Caribbean offshore waters were more under the influence of surface water masses from subtropical regions with negative $P-E$.

In summary, the model simulations indicate that increased precipitation during summer is the prevailing factor controlling the increased seasonality of the hydrological cycle in the southern Caribbean during the mid-Holocene (Fig. 11) as reconstructed from our monthly resolved coral $\delta^{18} \mathrm{O}_{\mathrm{sw}}$ records (Fig. 6). Moreover, the decrease in mean $\delta^{18} \mathrm{O}_{\mathrm{sw}}$ reconstructed from those records for the mid Holocene is 


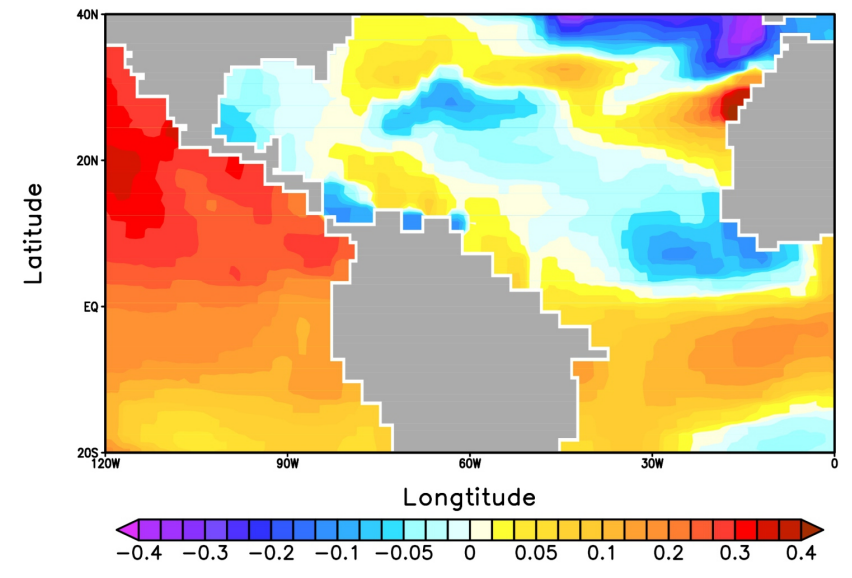

Fig. 12. Annual mean sea surface salinity anomaly (psu) at $6 \mathrm{ka}$ relative to pre-industrial, inferred from numerical simulations from the coupled general circulation model COSMOS.

consistent with the increased mean precipitation at that time as inferred from the model simulation (Figs. 3 and 11).

\subsection{Mid- to late Holocene transition}

The $6.22 \mathrm{ka}$ coral suggests a dominant effect through enhanced summer rainfall relative to advection of freshwater, whereas the three modern corals indicate less $P-E$, relative to the advection of freshwater as the prevailing factor controlling the annual cycle of sea surface hydrology. These differences suggest a transition since the mid-Holocene. The 4.27 and $3.79 \mathrm{ka}$ corals show high $\delta^{18} \mathrm{O}$ seasonality, having no phase lag with the corresponding $\mathrm{Sr} / \mathrm{Ca}$ record and suggesting that more negative (positive) $\delta^{18} \mathrm{O}$ values occurred in phase with warmer (colder) SST. This suggests wet summers and/or dry winters. As for the $6.22 \mathrm{ka}$ coral, "sharp" $\delta^{18} \mathrm{O}_{\mathrm{sw}}$ summer peaks towards more negative values are observed in the composite annual cycle, suggesting that wet summers were potentially characteristic during these time intervals. However, this "sharp" peak is less pronounced in more recent and especially in the modern coral records, suggesting that either loss of summer precipitation or reduced advection of fresher water through the Caribbean Current in summer occurred throughout the mid- to late Holocene, thus damping this "sharp" summer peak in the more recent coral records (Fig. 6). Moreover, the 3.83 and $1.84 \mathrm{ka}$ records indicate that the annual cycle of coral $\mathrm{Sr} / \mathrm{Ca}$ leads the corresponding annual cycle of $\delta^{18} \mathrm{O}$ by about half a month, suggesting that less (more) saline conditions occurred after maximum (minimum) SST values. One can infer from the measured coral $\mathrm{Sr} / \mathrm{Ca}$ and $\delta^{18} \mathrm{O}$ data that changes in the timing between annual SST and $\delta^{18} \mathrm{O}_{\mathrm{sw}}$ cycles occurred in the southern Caribbean Sea throughout the mid- to late Holocene. This gives rise to the possible competing influence of both the hydrological cycle and oceanic advection of freshwater on the annual hydrology.
An exceptionally large increased SST seasonality compared to both today and the mid-Holocene is indicated by the $2.35 \mathrm{ka}$ coral Sr/Ca record (Giry et al., 2010b, 2012). This is accompanied by a dampening of coral $\delta^{18} \mathrm{O}$ seasonality, resulting in a reversal of the reconstructed $\delta^{18} \mathrm{O}_{\mathrm{sw}}$ annual cycle, with more negative (positive) $\delta^{18} \mathrm{O}_{\mathrm{sw}}$ values in winter (summer). Considering local rainfall as the main driver of seasonal $\delta^{18} \mathrm{O}_{\mathrm{sw}}$ variations, enhanced precipitation/reduced evaporation during winter and/or reduced precipitation/enhanced evaporation during summer/fall relative to today could explain the annual $\Delta \delta^{18} \mathrm{O}$ cycle at $2.35 \mathrm{ka}$. However, reduced advection of freshwater during the warm season and/or enhanced advection during the cold season could be an alternate mechanism. With respect to the latter, surface winds would modulate both temperature (i.e. windinduced heat loss) and hydrological conditions (i.e. windinduced oceanic advection of freshwater from the south) at the sea surface. In this sense, weakened (strengthened) surface winds in summer (winter) could generate positive (negative) SST anomalies and reduced (intensified) transport of fresher water to the study site, thus explaining the increased SST seasonality and reversal of the annual hydrological cycle at $2.35 \mathrm{ka}$.

To summarise, summer precipitation dominated the annual hydrological cycle in the mid-Holocene. In contrast, enhanced evaporation in winter and oceanic advection of freshwater discharged from the Orinoco and the Amazon Rivers by wind-driven surface currents dominate the annual $\delta^{18} \mathrm{O}_{\mathrm{sw}}$ cycle at Bonaire today. This is consistent with the strengthening of easterly trade-winds associated with the southward migration of the ITCZ throughout the Holocene.

\subsection{Control of surface winds on surface temperature and hydrology}

From December through May, the Ekman transport induced by easterly trade winds causes upwelling at Cariaco Basin (Taylor et al., 2012). The source of the upwelled water is the more saline and colder Subtropical Underwater (Wüst, 1964). Consequently, if upwelling were the prevailing factor influencing sea surface hydrology at Bonaire, one would expect colder conditions to be accompanied by more saline conditions. However, as presented in Sect. 4.5 (cf. Fig. 9), the coral data show the opposite pattern (colder-less saline) throughout the mid- to late Holocene. Furthermore, the Cariaco upwelling occurs more than $300 \mathrm{~km}$ to the south east of Bonaire and the nutrient rich waters must be transported long enough to directly influence sea surface hydrology at Bonaire. Although there is evidence for short-lived upwelling events (filaments) that would bring cold and salty water to Bonaire at timescales of a day up to a week (cf. Andrade and Barton, 2005), these synoptic events are not long enough to be recorded in our monthly resolved coral records. Moreover, there is evidence for an eastward flow between Bonaire and the northern coast of Venezuela (cf. Fig. 5a from Andrade 
et al., 2003), whereas the typical westward flow of the Caribbean Current occurs north of the island. Consequently, while there might be a synoptic influence of the upwelling filaments at Bonaire, the dominant oceanographic features at this open-ocean location disable upwelled waters from Cariaco to be transported directly to Bonaire.

The coral $\mathrm{Sr} / \mathrm{Ca}-\mathrm{SST}$ and $\Delta \delta^{18} \mathrm{O}$ records reveal that warmer (colder) than average SST around Bonaire were characterised by more (less) saline conditions throughout the mid- to late Holocene (Fig. 2). This is true for quasi-biennial, interannual, near-decadal and multidecadal timescales (Fig. 9). On quasi-biennial timescales, the oscillation of zonal winds in the tropical troposphere is associated with sea level pressure anomalies and hurricane activity in the Atlantic (Gray, 1984). On interannual timescales, ENSO is known to be a major player in controlling both tropical Atlantic SST and precipitation (Alexander and Scott, 2002; Chiang et al., 2002; Giannini et al., 2000). El Niño results in an anomalously warm tropical North Atlantic, mainly through a warming of the tropical troposphere (Chiang et al., 2002). In addition, warming of the troposphere reduces convection and thus precipitation over the tropical Atlantic. Moreover, intense convection in the tropical Pacific associated with El Niño leads to suppression of rainfall over northern South America and the Amazon Basin (Garreaud et al., 2009). Although there are arguments that ENSO activity was reduced in the mid-Holocene (Clement et al., 1999; Tudhope et al., 2001), we find that the $6.22 \mathrm{ka}$ coral record shows a similar relationship between reconstructed salinity and SST at interannual timescales. On multidecadal timescales, the AMO is known to play a critical role in controlling tropical Atlantic SST and precipitation anomalies (Sutton and Hodson, 2005). During the AMO warm phase, the tropical Atlantic and Caribbean experience positive SST and positive summer precipitation anomalies, whereas summer precipitation over northern South America and the Amazon Basin shows an inverse relationship with the AMO (Sutton and Hodson, 2005).

Given the positive correlation between SST and salinity as documented in Bonaire coral records for a wide range of timescales, it is hypothesised that a single physical mechanism controlled this correlation over the last $6.2 \mathrm{ka}$. We propose that changes in the strength of zonal surface winds modulate both SST and the advection of tropical Atlantic freshwater into the southern Caribbean Sea (Fig. 13). In a previous study (Giry et al., 2012), we reported quasi-biennial to multidecadal variability of southern Caribbean SST as documented in our Bonaire coral $\mathrm{Sr} / \mathrm{Ca}$ records. Since SST and surface winds are strongly correlated around Bonaire (Fig. 9 from Wang, 2007), we assume that interannual to multidecadal changes of surface winds drive southern Caribbean SST variations on these timescales. Moreover, as the modern Caribbean throughflow shows strong wind-driven variations (e.g. Johns et al., 2002), we suggest that zonal surface winds force the inflow of fresher tropical water into the Caribbean

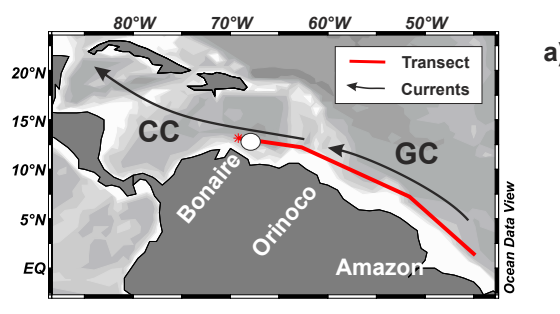

a)
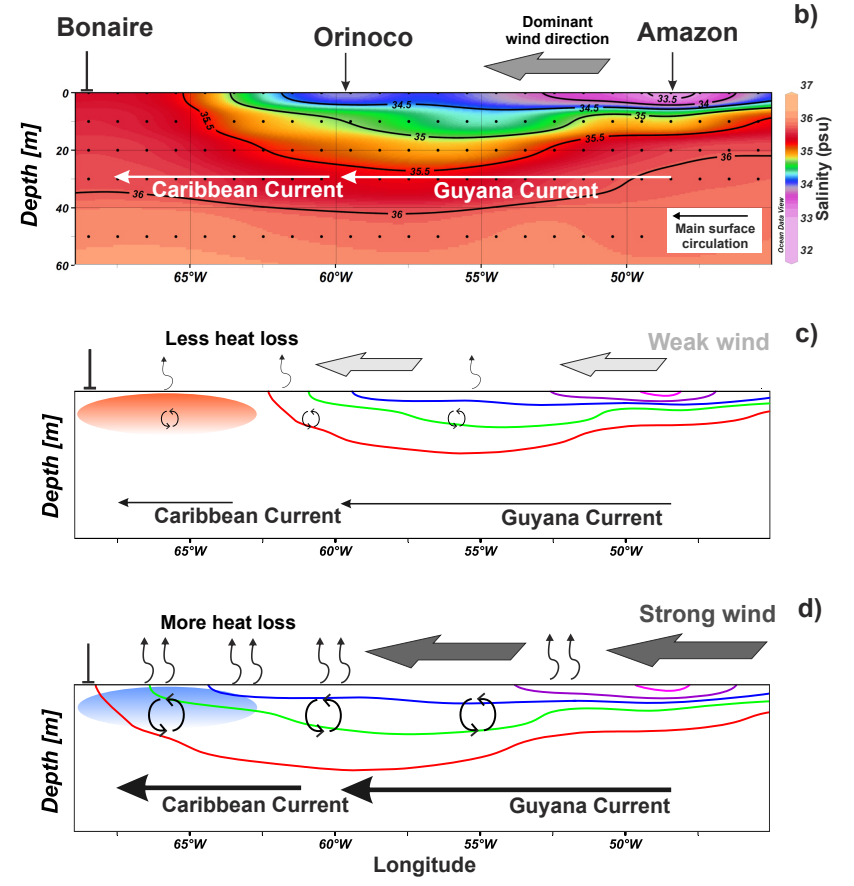

Fig. 13. (a) Map showing the transect of interest (red line) and the dominant surface currents (Guyana Current, GC; Caribbean Current, CC). (b) Observed sea surface salinity (SSS) in the upper $60 \mathrm{~m}$ along a transect from the western tropical Atlantic to the southeastern Caribbean Sea. Freshwater discharged by the Amazon and Orinoco rivers contribute to freshening of the western tropical Atlantic that extend northwestward due to transport by Guyana and Caribbean Currents. (c) and (d) Response of sea surface conditions under two different surface wind strength scenarios. (c) Weak wind scenario: reduced extent of fresh water (contour colour lines) transport northwestward due to reduced Guyana/Caribbean current system, and reduced heat loss and vertical mixing at sea surface that in turn contribute to warmer sea surface temperature (SST). (d) Strong wind scenario: intensification of surface water transport from the western tropical Atlantic to the Caribbean by surface current system and enhanced heat loss and vertical mixing at sea surface which in turn reduce SST, thus contributing to colder and less saline conditions around Bonaire.

via Ekman transport through the North Brazilian-GuyanaCaribbean current system. This is further supported by the high correlation coefficient found between annual mean SST and zonal surface wind and current at Bonaire (Fig. S2 in the Supplement). Moreover, this is consistent with a coral-based study from Puerto Rico (Kilbourne et al., 2007) which indicated that equatorial water is transported to the Caribbean by 
Ekman transport and is related to trade-winds variability. At Bonaire, strengthened easterlies contribute to stronger heat loss that cool down SST, while it forces Ekman transport and oceanic surface circulation that transport fresher tropical Atlantic water into the Caribbean, and thus contribute to colder and fresher conditions on interannual timescales in the southern Caribbean.

\subsection{Enhanced inter- to multidecadal variability of surface hydrology at $6.2 \mathrm{ka}$}

The Bonaire coral $\Delta \delta^{18} \mathrm{O}$ records indicate pronounced interto multidecadal periodicities (Fig. 7) suggesting a prominent feature of southern Caribbean Sea surface hydrology over the last $6.2 \mathrm{ka}$. The $6.22 \mathrm{ka}$ coral $\Delta \delta^{18} \mathrm{O}$ record shows enhanced variability at inter- to multidecadal timescales (Figs. 2, 7 and 8). Since Caribbean hydrology at $6 \mathrm{ka}$ was influenced by increased precipitation and more river runoff, the $\delta^{18} \mathrm{O}_{s w^{-}}$ salinity linear regression known in today's oceans might not be valid for the mid-Holocene (Craig and Gordon, 1965; Delaygue et al., 2000; Rohling and Bigg, 1998; Schmidt, 1999), thus hindering accurate quantification of past $\Delta \delta^{18} \mathrm{O}$ related salinity changes. Nevertheless, the amplitude of this multidecadal $\Delta \delta^{18} \mathrm{O}$ signal $(\sim 0.3 \%$ ) is larger than the corresponding annual cycle, thus providing evidence for enhanced multidecadal variability of southern Caribbean Sea surface hydrology during the mid-Holocene.

A coral $\delta^{18} \mathrm{O}$-based study from the Dominican Republic suggested interdecadal variability of tropical Atlantic precipitation in the mid-Holocene (Greer and Swart, 2006). It was suggested that the latitudinal migration of the ITCZ or increased storm activity have modulated interdecadal changes of northern Caribbean precipitation. In line with this, Knudsen et al. (2011) showed that precipitation over northern South America as inferred from the Cariaco Titanium record (Haug et al., 2001) has experienced multidecadal fluctuations linked to the AMO over the last $8 \mathrm{ka}$. A recent study showed that the southern Caribbean Sea experienced inter- to multidecadal variability of SST during the mid-Holocene Giry et al., 2012). All of which points to the important role of the atmospheric circulation in the inter- to multidecadal variability as documented in Bonaire corals records.

However, other mechanisms could explain the positive correlation between SSS and SST and possibly the enhanced inter- to multidecadal variability in the mid-Holocene as documented in Bonaire coral records. On multidecadal timescales, the AMO can be assumed to be partly linked to the strength of the AMOC (Delworth and Mann, 2000; Knight et al., 2005; Wei and Lohmann, 2012). There is a general agreement from water hosing experiments that a slowdown of the AMOC cools down most of the North Atlantic (Stouffer et al., 2006). However, similar experiments using a high-resolution coupled ocean-atmosphere model (Wan et al., 2009) revealed that a weakened AMOC indeed produces surface cooling in the North Atlantic, whereas a narrow strip of warmer surface water appears along the northern coast of South America. Wan et al. (2009) suggested that a weakening of the AMOC produces a weakening of the western boundary current, which in turn creates a strong subsurface warming that extends to the surface mixed layer (such feature is actually seen also in coarse-resolution models, e.g. in Lohmann, 2003 and some of the models mentioned in Stouffer et al., 2006). In addition, there is a general consensus in water hosing experiments that the mean position of the ITCZ is shifted southward during a weakened AMOC resulting in negative precipitation anomalies over the northern tropical Atlantic and northern South America (e.g. Stouffer et al., 2006; Zhang and Delworth, 2005; Lohmann, 2003; Vellinga and Wood, 2002). This is consistent with the modelling results of Wan et al. (2010), indicating that atmospheric responses to reduced AMOC would increase salinity in the Caribbean. Given that changes from warm and saline to cold and fresh conditions in the southern Caribbean Sea were observed during periods of weakened large-scale ocean circulation (e.g. Younger Dryas) (Rühlemann et al., 1999; Schmidt et al., 2004), our study indicates that on inter- to multidecadal timescales, a scale relevant for ocean circulation, changes in AMOC strength could partially explain the positive relationship between SST and SSS derived from Bonaire coral records. Moreover, if this were proven true, enhanced climate variability observed in the mid-Holocene Caribbean climate (e.g. Greer and Swart, 2006; Giry et al., 2012) would reflect multidecadal variability potentially linked to changes in the strength of the AMOC. Finally, this would suggest that in-phase variations between the ocean and the atmosphere would create strong inter- to multidecadal climate variability.

\section{Conclusions}

Seasonality and interannual to multidecadal variability of surface hydrology in the southern Caribbean Sea are investigated for time windows of several decades throughout the mid- to late Holocene, by using monthly resolved $\mathrm{Sr} / \mathrm{Ca}$ and $\delta^{18} \mathrm{O}$ records of Bonaire corals. Derived coral $\Delta \delta^{18} \mathrm{O}$ is used as a proxy for the oxygen isotopic composition of the surface seawater $\left(\delta^{18} \mathrm{O}_{\mathrm{sw}}\right)$. While this study indicates less saline mean conditions during the mid-Holocene compared to today, seasonality and interannual to multidecadal variability of the sea surface hydrology can be summarised as follows:

1. Consistent with modern southern Caribbean surfacewater hydrology, the large positive deviation of the coral $\Delta \delta^{18} \mathrm{O}$ annual cycle in the late part of the year supports that enhanced evaporation and reduced advection of fresher surface waters from the Orinoco and Amazon rivers in winter are the dominant factors controlling the annual $\delta^{18} \mathrm{O}_{\mathrm{sw}}$ cycle as inferred from three modern corals. 
2. The $6.22 \mathrm{ka}$ coral $\delta^{18} \mathrm{O}$ record indicates increased seasonality of the annual hydrological cycle during the mid-Holocene. This increased seasonality is very likely induced by enhanced precipitation in summer as inferred from both climate model simulations and the corresponding annual $\Delta \delta^{18} \mathrm{O}$ cycle.

3. On interannual to multidecadal timescales, coral $\mathrm{Sr} / \mathrm{Ca}$ and $\Delta \delta^{18} \mathrm{O}$ reveal that warmer than average conditions at the sea surface were characterised by more saline conditions and vice versa. Since this systematic relationship is found for very short timescales relevant for atmospheric circulation, we propose that the surface wind-driven advection of fresher surface waters from the Amazon and Orinoco rivers to the Caribbean explains the positive correlation between SST and salinity documented in Bonaire coral records. A potential link to variations in the strength of the AMOC on these timescales is hypothesized.

4. Our mid-Holocene coral $\Delta \delta^{18} \mathrm{O}$ record provides evidence for enhanced inter- to multidecadal variability of the sea surface hydrology at that time. Although an accurate quantification of the relative salinity changes is difficult to infer, the record indicates that the amplitude of the inter- to multidecadal variability exceeds the corresponding annual cycle at $6.22 \mathrm{kaBP}$.

This study identified both the freshwater flux $P-E$ and oceanic advection of fresher surface waters by wind-driven surface currents as the prevailing factors influencing the freshwater budget of the southern Caribbean during the midto late Holocene. Since the density structure of North Atlantic water can have drastic impacts on ocean circulation patterns and heat transport from low to high latitudes, we propose further investigating interannual to multidecadal variability of the western tropical Atlantic and riverine discharge from South American tropical rivers as a potential feedback mechanism affecting the strength of the AMOC.

\section{Supplementary material related to this article is

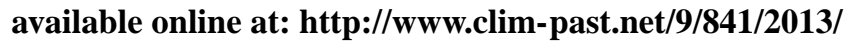 cp-9-841-2013-supplement.pdf.}

Acknowledgements. We thank the government of the Island Territory of Bonaire (former Netherlands Antilles) for research and fieldwork permission, E. Beukenboom (STINAPA Bonaire National Parks Foundation) for support, J. Pätzold for support with coral drilling and discussion, M. Segl and her team for stable isotope analysis, and S. Pape for operating and maintaining the ICP-OES. This work was funded by Deutsche Forschungsgemeinschaft (DFG) under the Priority Programme INTERDYNAMIK, through grants to T. F. (FE 615/3-1, 3-2; CaribClim).

Edited by: M. Schulz

\section{References}

Abram, N. J., Gagan, M. K., Liu, Z., Hantoro, W. S., McCulloch, M. T., and Suwargadi, B. W. : Seasonal Characteristics of the Indian Ocean Dipole during the Holocene epoch, Nature, 445, 299-302, 2007.

Abram, N. J., McGregor, H. V., Gagan, M. K., Hantoro, W. S., and Suwargadi, B. W.: Oscillations in the southern extent of the IndoPacific Warm Pool during the mid-Holocene, Quaternary Sci. Rev., 28, 2794-2803, 2009.

Alexander, M. and Scott, J.: The influence of ENSO on airsea interaction in the Atlantic, Geophys. Res. Lett., 29, 1701, doi:10.1029/2001g1014347, 2002.

Andrade, C. A. and Barton, E. D.: The Guajira upwelling system, Continental Shelf Research, 25, 1003-1022, doi:10.1016/j.csr.2004.12.012, 2005.

Andrade, C. A., Barton, E. D., and Mooers, C. N. K.: Evidence for an eastward flow along the Central and South American Caribbean Coast, J. Geophys. Res., 108, 3185, doi:10.1029/2002JC001549, 2003.

Antonov, J. I., Locarnini, R. A., Boyer, T. P., Mishonov, A. V., and Garcia, H. E.: World Ocean Atlas 2005, in: Volume 2: Salinity, edited by: Levitus, S., NOAA Atlas NESDIS 62, US Government Printing Office, Washington, DC, 182 pp., 2006.

Antonov, J. I., Seidov, D., Boyer, T. P., Locarnini, R. A., Mishonov, A. V., Garcia, H. E., Baranova, O. K., Zweng, M. M., and Johnson, D. R.: World Ocean Atlas 2009, in: Volume 2: Salinity, edited by: Levitus, S., NOAA Atlas NESDIS 69, US Government Printing Office, Washington, DC, 184 pp., 2010.

Beck, J. W., Edwards, R. L., Ito, E., Taylor, F. W., Recy, J., Rougerie, F., Joannot, P., and Henin, C.: Sea-Surface Temperature from Coral Skeletal Strontium/Calcium Ratios, Science, 257, 644-647, 1992.

Cahyarini, S. Y., Pfeiffer, M., Timm, O., Dullo, W.-C., and Schönberg, D. G.: Reconstructing seawater $\delta^{18} \mathrm{O}$ from paired coral $\delta^{18} \mathrm{O}$ and $\mathrm{Sr} / \mathrm{Ca}$ ratios: Methods, error analysis and problems, with examples from Tahiti (French Polynesia) and Timor (Indonesia), Geochim. Cosmochim. Acta, 72, 2841-2853, 2008.

Carlson, A. E., Oppo, D. W., Came, R. E., LeGrande, A. N., Keigwin, L. D., and Curry, W. B.: Subtropical Atlantic salinity variability and Atlantic meridional circulation during the last deglaciation, Geology, 36, 991-994, doi:10.1130/g25080a.1, 2008.

Carriquiry, J., Risk, M. J., and Schwarcz, H. P.: Stable isotope geochemistry of corals from Costa Rica as proxy indicator of the EL Niño/southern Oscillation (ENSO), Geochim. Cosmochim. Acta, 58, 335-351, 1994.

Carton, J. A. and Giese, B. S.: A Reanalysis of Ocean Climate Using Simple Ocean Data Assimilation (SODA), Mon. Weather Rev., 136, 2999-3017, 2008.

Chérubin, L. M. and Richardson, P. L.: Caribbean current variability and the influence of the Amazon and Orinoco freshwater plumes, Deep-Sea Res. Pt. I, 54, 1451-1473, 2007.

Chiang, J. C. H., Kushnir, Y., and Giannini, A.: Deconstructing Atlantic Intertropical Convergence Zone variability: Influence of the local cross-equatorial sea surface temperature gradient and remote forcing from the eastern equatorial Pacific, J. Geophys. Res., 107, 4004, doi:10.1029/2000jd000307, 2002. 
Clement, A. C., Seager, R., and Cane, M. A.: Orbital Controls on the El Niño/Southern Oscillation and the Tropical Climate, Paleoceanography, 14, 441-456, doi:10.1029/1999pa900013, 1999.

Corrège, T.: Sea surface temperature and salinity reconstruction from coral geochemical tracers, Palaeogeogr. Palaeoclimatol. Palaeoecol., 232, 408-428, 2006.

Craig, H. and Gordon, L. I. (Eds.): Deuterium and oxygen 18 variations in the ocean and the marine atmosphere. Stable Isotopes in Oceanographic Studies and Paleotemperatures, Cons. Naz. di Rech., Spoleto, Italy, 121 pp., 1965.

Delaygue, G., Jouzel, J., and Dutay, J.-C.: Oxygen 18-salinity relationship simulated by an oceanic general circulation model, Earth Planet. Sci. Lett., 178, 113-123, 2000.

Delworth, T. L. and Mann, M. E.: Observed and simulated multidecadal variability in the Northern Hemisphere, Clim. Dynam., 16, 661-676, doi:10.1007/s003820000075, 2000.

Dima, M. and Lohmann, G.: A Hemispheric Mechanism for the Atlantic Multidecadal Oscillation, J. Climate, 20, 2706-2719, doi:10.1175/jcli4174.1, 2007.

Etter, P. C., Lamb, P. J., and Portis, D. H.: Heat and Freshwater Budgets of the Caribbean Sea with Revised Estimates for the Central American Seas, J. Phys. Oceanogr., 17, 1232-1248, doi:10.1175/1520-0485(1987)017<1232:HAFBOT>2.0.CO;2, 1987.

Felis, T., Pätzold, J., and Loya, Y.: Mean oxygen-isotope signatures in Porites spp. corals: inter-colony variability and correction for extension-rate effects, Coral Reefs, 22, 328-336, 2003.

Felis, T., Lohmann, G., Kuhnert, H., Lorenz, S. J., Scholz, D., Pätzold, J., Al-Rousan, S. A., and Al-Moghrabi, S. M.: Increased seasonality in Middle East temperatures during the last interglacial period, Nature, 429, 164-168, 2004.

Felis, T., Suzuki, A., Kuhnert, H., Dima, M., Lohmann, G., and Kawahata, H.: Subtropical coral reveals abrupt early-twentiethcentury freshening in the western North Pacific Ocean, Geology, 37, 527-530, 2009.

Felis, T., Merkel, U., Asami, R., Deschamps, P., Hathorne, E. C., Kölling, M., Bard, E., Cabioch, G., Durand, N., Prange, M., Schulz, M., Cahyarini, S. Y., and Pfeiffer, M.: Pronounced interannual variability in tropical South Pacific temperatures during Heinrich Stadial 1, Nat. Commun., 3, 965, doi:10.1038/ncomms1973, 2012.

Fleitmann, D., Burns, S. J., Mudelsee, M., Neff, U., Kramers, J., Mangini, A., and Matter, A.: Holocene Forcing of the Indian Monsoon Recorded in a Stalagmite from Southern Oman, Science, 300, 1737-1739, doi:10.1126/science.1083130, 2003.

Fratantoni, D. M.: North Atlantic surface circulation during the 1990's observed with satellite-tracked drifters, J. Geophys. Res., 106, 22067-22093, doi:10.1029/2000jc000730, 2001.

Gagan, M. K., Ayliffe, L. K., Hopley, D., Cali, J. A., Mortimer, G. E., Chappell, J., McCulloch, M. T., and Head, M. J.: Temperature and Surface-Ocean Water Balance of the Mid-Holocene Tropical Western Pacific, Science, 279, 1014-1018, 1998.

Garreaud, R. D., Vuille, M., Compagnucci, R., and Marengo, J.: Present-day South American climate, Palaeogeogr. Palaeoclimatol. Palaeoecol., 281, 180-195, 2009.

Ghil, M., Allen, M. R., Dettinger, M. D., Ide, K., Kondrashov, D., Mann, M. E., Robertson, A. W., Saunders, A., Tian, Y., Varadi, F., and Yiou, P.: Advanced spectral methods for climatic time series, Rev. Geophys., 40, 1003, doi:10.1029/2000rg000092, 2002.
Giannini, A., Kushnir, Y., and Cane, M. A.: Interannual Variability of Caribbean Rainfall, ENSO, and the Atlantic Ocean, J. Climate, 13, 297-311, 2000.

Giannini, A., Chiang, J. C. H., Cane, M. A., Kushnir, Y., and Seager, R.: The ENSO Teleconnection to the Tropical Atlantic Ocean: Contributions of the Remote and Local SSTs to Rainfall Variability in the Tropical Americas, J. Climate, 14, 4530-4544, doi:10.1175/1520-0442(2001)014<4530:TETTTT>2.0.CO;2, 2001.

Giry, C., Felis, T., Kölling, M., and Scheffers, S.: Geochemistry and skeletal structure of Diploria strigosa, implications for coral-based climate reconstruction, Palaeogeogr. Palaeoclimatol. Palaeoecol., 298, 378-387, 2010a.

Giry, C., Felis, T., Scheffers, S., and Fensterer, C.: Assessing the potential of Southern Caribbean corals for reconstructions of Holocene temperature variability, IOP Conference Series: Earth and Environmental Science, 9, doi:10.1088/17551315/9/1/012021, 2010b.

Giry, C., Felis, T., Kölling, M., Scholz, D., Wei, W., Lohmann, G., and Scheffers, S.: Mid- to late Holocene changes in tropical Atlantic temperature seasonality and interannual to multidecadal variability documented in southern Caribbean corals, Earth Planet. Sci. Lett., 331-332, 187-200, 2012.

Gordon, A. L.: Circulation of the Caribbean Sea, J. Geophys. Res., 72, 6207-6223, doi:10.1029/JZ072i024p06207, 1967.

Gray, W. M.: Atlantic Seasonal Hurricane Frequency, Part I: El Niño and $30 \mathrm{mb}$ Quasi-Biennial Oscillation Influences, Mon. Weather Rev., 112, 1649-1668, doi:10.1175/15200493(1984)112<1649:ASHFPI> 2.0.CO;2, 1984.

Greer, L. and Swart, P. K.: Decadal cyclicity of regional midHolocene precipitation: Evidence from Dominican coral proxies, Paleoceanography, 21, PA2020, doi:10.1029/2005PA001166, 2006.

Hastenrath, S.: Interannual Variability and Annual Cycle: Mechanisms of Circulation and Climate in the Tropical Atlantic Sector, Mon. Weather Rev., 112, 1097-1107, doi:10.1175/15200493(1984)112<1097:IVAACM>2.0.CO;2, 1984.

Hastenrath, S. and Lamb, P. J.: Heat Budget Atlas of the Tropical Atlantic and Eastern Pacific Oceans, University of Winconsin Press, 104 pp., 1978.

Haug, G. H., Hughen, K. A., Sigman, D. M., Peterson, L. C., and Rohl, U.: Southward Migration of the Intertropical Convergence Zone Through the Holocene, Science, 293, 1304-1308, 2001.

Hellweger, F. L. and Gordon, A. L.: Tracing Amazon River water into the Caribbean Sea, J. Mar. Res., 60, 537-549, 2002.

Hendy, E. J., Gagan, M. K., Alibert, C. A., McCulloch, M. T., Lough, J. M., and Isdale, P. J.: Abrupt Decrease in Tropical Pacific Sea Surface Salinity at End of Little Ice Age, Science, 295, 1511-1514, 2002.

Hernández, Guerra, A., and Joyce, T. M.: Water masses and circulation in the surface layers of the Caribbean at $66^{\circ} \mathrm{W}$, Geophys. Res. Lett., 27, 3497-3500, doi:10.1029/1999g1011230, 2000.

Hetzinger, S., Pfeiffer, M., Dullo, W.-C., Ruprecht, E., and GarbeSchönberg, D.: $\mathrm{Sr} / \mathrm{Ca}$ and $\delta^{18} \mathrm{O}$ in a fast-growing Diploria strigosa coral: Evaluation of a new climate archive for the tropical Atlantic, Geochem. Geophy. Geosy., 7, Q10002, doi:10.1029/2006GC001347, 2006. 
Hetzinger, S., Pfeiffer, M., Dullo, W.-C., Garbe-Schönberg, D., and Halfar, J.: Rapid 20th century warming in the Caribbean and impact of remote forcing on climate in the northern tropical Atlantic as recorded in a Guadeloupe coral, Palaeogeogr. Palaeoclimatol. Palaeoecol., 296, 111-124, 2010.

Hodell, D. A., Curtis, J. H., Jones, G. A., Higuera-Gundy, A., Brenner, M., Binford, M. W., and Dorsey, K. T.: Reconstruction of Caribbean climate change over the past 10,500 years, Nature, 352, 790-793, 1991.

Hulme, M., Osborn, T. J., and Johns, T. C.: Precipitation sensitivity to global warming: Comparison of observations with HadCM2 simulations, Geophys. Res. Lett., 25, 3379-3382, doi:10.1029/98gl02562, 1998.

Jaeschke, A., Rühlemann, C., Arz, H., Heil, G., and Lohmann, G.: Coupling of millennial-scale changes in sea surface temperature and precipitation off northeastern Brazil with high latitude climate shifts during the last glacial period, Paleoceanography, 22, PA4206, doi:10.1029/2006PA001391, 2007.

Johns, W. E., Townsend, T. L., Fratantoni, D. M., and Wilson, W. D.: On the Atlantic inflow to the Caribbean Sea, Deep-Sea Res. Pt. I, 49, 211-243, 2002.

Kilbourne, K., Quinn, T., Guilderson, T., Webb, R., and Taylor, F.: Decadal- to interannual-scale source water variations in the Caribbean Sea recorded by Puerto Rican coral radiocarbon, Clim. Dynam., 29, 51-62, doi:10.1007/s00382-007-0224-2, 2007.

Knight, J. R., Allan, R. J., Folland, C. K., Vellinga, M., and Mann, M. E.: A signature of persistent natural thermohaline circulation cycles in observed climate, Geophys. Res. Lett., 32, L20708, doi:10.1029/2005g1024233, 2005.

Knudsen, M. F., Seidenkrantz, M.-S., Jacobsen, B. H., and Kuijpers, A.: Tracking the Atlantic Multidecadal Oscillation through the last 8,000 years, Nat. Commun., 2, 178, 2011.

Larsen, J. C.: Transport and Heat Flux of the Florida Current at 27 degrees N Derived from Cross-Stream Voltages and Profiling Data: Theory and Observations, Philos. T. Phys. Sci. Eng., 338, 169-236, 1992.

Leduc, G., Vidal, L., Tachikawa, K., Rostek, F., Sonzogni, C., Beaufort, L., and Bard, E.: Moisture transport across Central America as a positive feedback on abrupt climatic changes, Nature, 445 , 908-911, 2007.

LeGrande, A. N. and Schmidt, G. A.: Global gridded data set of the oxygen isotopic composition in seawater, Geophys. Res. Lett., 33, L12604, doi:10.1029/2006g1026011, 2006.

Linsley, B. K., Kaplan, A., Gouriou, Y., Salinger, J., deMenocal, P. B., Wellington, G. M., and Howe, S. S.: Tracking the extent of the South Pacific Convergence Zone since the early 1600s, Geochem. Geophy. Geosy., 7, Q05003, doi:05010.01029/02005GC001115., 2006.

Lohmann, G.: Atmospheric and oceanic freshwater transport during weak Atlantic overturning circulation, Tellus A, 55, 438-449, doi:10.1034/j.1600-0870.2003.00028.x, 2003.

Mann, M. E. and Lees, J. M.: Robust estimation of background noiseand signal detection in climatic time series, Climate Change, 33, 409-445, doi:10.1007/bf00142586, 1996.

Marsland, S., Haak, H., Jungclaus, J., Latif, M., and Röske, F.: The Max-Planck-Institute global ocean/sea ice model with orthogonal curvilinear coordinates, Ocean Model., 5, 91-127, 2003.
Martis, A., van Oldenborgh, G. J., and Burgers, G.: Predicting rainfall in the Dutch Caribbean-more than El Niño?, Int. J. Climatol., 22, 1219-1234, doi:10.1002/joc.779, 2002.

McCulloch, M. T., Gagan, M. K., Mortimer, G. E., Chivas, A. R., and Isdale, P. J.: A high-resolution $\mathrm{Sr} / \mathrm{Ca}$ and $\delta^{18} \mathrm{O}$ coral record from the Great Barrier Reef, Australia, and the 1982-1983 El Niño, Geochim. Cosmochim. Acta, 58, 2747-2754, 1994.

Molinari, R. L., Johns, E., and Festa, J. F.: The Annual Cycle of Meridional Heat Flux in the Atlantic Ocean at $26.5^{\circ}$ N, J. Phys. Oceanogr., 20, 476-482, doi:10.1175/15200485(1990)020<0476:TACOMH>2.0.CO;2, 1990.

Müller-Karger, F. E., McClain, C. R., Fisher, T. R., Esaias, W. E., and Varela, R.: Pigment distribution in the Caribbean sea: Observations from space, Prog. Oceanogr., 23, 23-64, 1989.

Oppo, D. W., Schmidt, G. A., and LeGrande, A. N.: Seawater isotope constraints on tropical hydrology during the Holocene, Geophys. Res. Lett., 34, L13701, doi:10.1029/2007gl030017, 2007.

Paillard, D., Labeyrie, L., and Yiou, P.: Macintosh program performs time-series analysis, EOS Trans. AGU, 77, 379, 1996.

Raddatz, T., Reick, C., Knorr, W., Kattge, J., Roeckner, E., Schnur, R., Schnitzler, K. G., Wetzel, P., and Jungclaus, J.: Will the tropical land biosphere dominate the climate-carbon cycle feedback during the twenty-first century?, Clim. Dynam., 29, 565-574, doi:10.1007/s00382-007-0247-8, 2007.

Ren, L., Linsley, B. K., Wellington, G. M., Schrag, D. P., and Hoegh-guldberg, O.: Deconvolving the $\delta^{18} \mathrm{O}$ seawater component from subseasonal coral $\delta^{18} \mathrm{O}$ and $\mathrm{Sr} / \mathrm{Ca}$ at Rarotonga in the southwestern subtropical Pacific for the period 1726 to 1997 , Geochim. Cosmochim. Acta, 67, 1609-1621, 2003.

Reverdin, G., Kestenare, E., Frankignoul, C., and Delcroix, T.: In situ surface salinity in the tropical and subtropical Atlantic Ocean, Part I. Large scale variability, Progr. Oceanogr., 73, 311340, 2007.

Roeckner, E., Bäuml, G., Bonaventura, L., Brokopf, R., Esch, M., Giorgetta, M., Hagemann, S., Kirchner, I., Kornblueh, L., Manzini, E., Rhodin, A., Schlese, U., Schulzweida, U., and Tompkins, A.: The Atmospheric General Circulation Model ECHAM5, Part One: Model Description Report No. 349, Max Planck Institute for Meteorology, 2003.

Rohling, E. J. and Bigg, G. R.: Paleosalinity and $\delta^{18} \mathrm{O}$ : A critical assessment, J. Geophys. Res., 103, 1307-1318, doi:10.1029/97jc01047, 1998.

Rühlemann, C., Mulitza, S., Muller, P. J., Wefer, G., and Zahn, R.: Warming of the tropical Atlantic Ocean and slowdown of thermohaline circulation during the last deglaciation, Nature, 402, 511-514, 1999.

Schmidt, G. A.: Forward Modeling of Carbonate Proxy Data from Planktonic Foraminifera Using Oxygen Isotope Tracers in a Global Ocean Model, Paleoceanography, 14, 482-497, doi:10.1029/1999pa900025, 1999.

Schmidt, M. W. and Spero, H. J.: Meridional shifts in the marine ITCZ and the tropical hydrologic cycle over the last three glacial cycles, Paleoceanography, 26, PA1206, doi:10.1029/2010pa001976, 2011.

Schmidt, M. W., Spero, H. J., and Lea, D. W.: Links between salinity variation in the Caribbean and North Atlantic thermohaline circulation, Nature, 428, 160-163, 2004. 
Schott, F. A., Lee, T. N., and Zantopp, R.: Variability of Structure and Transport of the Florida Current in the Period Range of Days to Seasonal, J. Phys. Oceanogr., 18, 1209-1230, doi:10.1175/1520-0485(1988)018<1209:VOSATO > 2.0.CO;2, 1988.

Sepulcre, S., Vidal, L., Tachikawa, K., Rostek, F., and Bard, E.: Sea-surface salinity variations in the northern Caribbean Sea across the Mid-Pleistocene Transition, Clim. Past, 7, 75-90, doi:10.5194/cp-7-75-2011, 2011.

Smith, S. V., Buddemeier, R. W., Redalje, R. C., and Houck, J. E.: Strontium-Calcium Thermometry in Coral Skeletons, Science, 204, 404-407, doi:10.1126/science.204.4391.404, 1979.

Smith, T. M., Reynolds, R. W., Peterson, T. C., and Lawrimore, J.: Improvements to NOAA's Historical Merged Land-Ocean Surface Temperature Analysis (1880-2006), J. Climate, 21, $2283-$ 2296, 2008.

Stouffer, R. J., Yin, J., Gregory, J. M., Dixon, K. W., Spelman, M. J., Hurlin, W., Weaver, A. J., Eby, M., Flato, G. M., Hasumi, H., Hu, A., Jungclaus, J. H., Kamenkovich, I. V., Levermann, A., Montoya, M., Murakami, S., Nawrath, S., Oka, A., Peltier, W. R., Robitaille, D. Y., Sokolov, A., Vettoretti, G., and Weber, S. L.: Investigating the Causes of the Response of the Thermohaline Circulation to Past and Future Climate Changes, J. Climate, 19, 1365-1387, doi:10.1175/JCLI3689.1, 2006.

Sutton, R. T. and Hodson, D. L. R.: Atlantic Ocean Forcing of North American and European Summer Climate, Science, 309, 115118, doi:10.1126/science.1109496, 2005.

Taylor, G. T., Muller-Karger, F. E., Thunell, R. C., Scranton, M. I., Astor, Y., Varela, R., Ghinaglia, L. T., Lorenzoni, L., Fanning, K. A., Hameed, S., and Doherty, O.: Ecosystem responses in the southern Caribbean Sea to global climate change, P. Natl. Acad. Sci., 109, 19315-19320, doi:10.1073/pnas.1207514109, 2012.

Tudhope, A. W., Chilcott, C. P., McCulloch, M. T., Cook, E. R., Chappell, J., Ellam, R. M., Lea, D. W., Lough, J. M., and Shimmield, G. B.: Variability in the El Niño-Southern Oscillation Through a Glacial-Interglacial Cycle, Science, 291, 1511-1517, 2001.

Urey, H. C.: The thermodynamic properties of isotopic substances, J. Chem. Soc., 1947, 562-581, 1947.

Vellinga, M. and Wood, R. A.: Global Climatic Impacts of a Collapse of the Atlantic Thermohaline Circulation, Climatic Change, 54, 251-267, doi:10.1023/a:1016168827653, 2002.
Wan, X., Chang, P., Saravanan, R., Zhang, R., and Schmidt, M. W.: On the interpretation of Caribbean paleo-temperature reconstructions during the Younger Dryas, Geophys. Res. Lett., 36, L02701, doi:10.1029/2008g1035805, 2009.

Wan, X., Chang, P., and Schmidt, M. W.: Causes of tropical Atlantic paleo-salinity variation during periods of reduced AMOC, Geophys. Res. Lett., 37, L04603, doi:10.1029/2009g1042013, 2010.

Wang, C.: Variability of the Caribbean Low-Level Jet and its relations to climate, Clim. Dynam., 29, 411-422, doi:10.1007/s00382-007-0243-z, 2007.

Watanabe, T., Winter, A., and Oba, T.: Seasonal changes in sea surface temperature and salinity during the Little Ice Age in the Caribbean Sea deduced from $\mathrm{Mg} / \mathrm{Ca}$ and $18 \mathrm{O} / 16 \mathrm{O}$ ratios in corals, Mar. Geol., 173, 21-35, 2001.

Wei, W. and Lohmann, G.: Simulated Atlantic Multidecadal Oscillation during the Holocene, J. Climate, 25, 6989-7002, doi:10.1175/JCLI-D-11-00667.1, 2012.

Wei, W., Lohmann, G., and Dima, M.: Distinct Modes of Internal Variability in the Global Meridional Overturning Circulation Associated with the Southern Hemisphere Westerly Winds, J. Phys. Oceanogr., 42, 785-801, doi:10.1175/jpo-d-11-038.1, 2012.

Wellington, G. M., Dunbar, R. B., and Merlen, G.: Calibration of Stable Oxygen Isotope Signatures in Galápagos Corals, Paleoceanography, 11, 467-480, doi:10.1029/96pa01023, 1996.

Wüst, G.: Stratification and Circulation in the Antillean-Caribbean Basins, Part 1, Spreading and mixing of the water types with an oceanographic atlas, Columbia University Press, New York, 201 pp., 1964.

Yokoyama, Y., Suzuki, A., Siringan, F., Maeda, Y., Abe-Ouchi, A., Ohgaito, R., Kawahata, H., and Matsuzaki, H.; Mid-Holocene palaeoceanography of the northern South China Sea using coupled fossil-modern coral and atmosphere-ocean GCM model, Geophys. Res. Lett., 38, L00F03, doi:10.1029/2010GL044231, 2011.

Zhang, D., Msadek, R., McPhaden, M. J., and Delworth, T.: Multidecadal variability of the North Brazil Current and its connection to the Atlantic meridional overturning circulation, J. Geophys. Res., 116, C04012, doi:10.1029/2010jc006812, 2011.

Zhang, R. and Delworth, T. L.: Simulated Tropical Response to a Substantial Weakening of the Atlantic Thermohaline Circulation, J. Climate, 18, 1853-1860, doi:10.1175/JCLI3460.1, 2005. 